\title{
ARTICLE
}

\section{THE POLITICS OF ARBITRATION LAW AND CENTRIST PROPOSALS FOR REFORM}

\author{
STEPHEN J. WARE* \\ TABLE of Contents
}

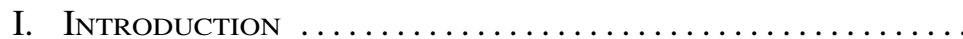

II. The Political Divide Over Law Governing Adhesive Arbitration Agreements.........................

III. Framework to Understand the Arbitration Debate: Requiring Different Levels of Consent to Trade Away the Right to Litigate.............................. 725

A. Five Positions on a Left-Right Continuum ........... 725

B. Trading Away the Right to Litigate................ 727

1. Settlement Agreements and Exculpatory Clauses ... 727

2. Default Rules and Mandatory Rules........... 730

C. The Very Progressive Position on Arbitration: Enforce No Pre-Dispute Arbitration Agreements ............ 732

D. The Moderately Progressive Position on Arbitration: Enforce Non-Adhesive Pre-Dispute Arbitration Agreements ...............................

E. The Centrist Position on Arbitration: Treat Adhesive Arbitration Agreements Like Other Adhesion Contracts .................................

F. The Moderately Conservative Position on Arbitration: The Separability Doctrine ..................... 741

G. The Very Conservative Position: Converting Some Arbitration Agreements into Exculpatory Clauses ......

1. Legally-Erroneous Decisions .................. 744

2. Class Action "Waivers" .................. 745

IV. Current Law's Place on the Continuum and Proposals FOR REFORM .................................. 746

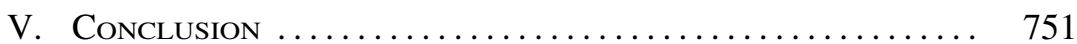
ApPendix: A Proposed CFPB Rule .......................... 752

* Professor of Law, University of Kansas School of Law. Thanks to Chris Drahozal, Sarah Cole, Nancy Welsh, Maureen Weston, Ron Aronovsky, Jean Sternlight, Jessica Berch, Tom Stacy, and Michael Green for comments and to Tyler Holmes, Abigail West, Mark Wilkins, Tyler Manson, Catherine Zollicker, Kelley Reynolds, and Tim Bogner for helpful research assistance. 
Arbitration law in the United States is far more controversial when applied to individuals than to businesses. While enforcement of arbitration agreements between businesses sometimes raises legal issues that divide courts, those issues tend to interest only scholars, lawyers, and other specialists in the field of arbitration. In contrast, enforcement of arbitration agreements between a business and an individual (such as a consumer or employee) raises legal issues that interest many members of Congress and various interest groups, all of whom have taken positions on significant proposals for law reform. The Consumer Financial Protection Bureau has extensively researched and reported on consumer arbitration agreements and is expected to issue a rule regulating, or even prohibiting, such agreements.

This Article both explains how issues surrounding consumer and other adhesive arbitration agreements became divisive along predictable political lines and introduces a framework to understand and compare various positions on them. This new framework arrays on a continuum five positions on the level of consent the law should require before enforcing an arbitration agreement against an individual. Progressives generally would require higher levels of consent than arbitration law currently requires, while conservatives generally defend current arbitration law's low standards of consent.

This Article proposes a centrist position. It joins progressives in rejecting overbroad enforcement of adhesive arbitration agreements due to conservativesupported anomalies in arbitration law's treatment of contract-law defenses, legally-erroneous decisions, and class actions. Once these anomalies are fixed, though, this Article joins conservatives in defending general enforcement of adhesive arbitration agreements under contract law's standards of consent because adhesive arbitration agreements should_contrary to progressive opinions-be as generally enforceable as other adhesion contracts. This Article briefly concludes by proposing language for a rule the Consumer Financial Protection Bureau could adopt to enact the reforms advocated in this Article.

\section{INTRODUCTION}

The Federal Arbitration Act ("FAA"), ${ }^{1}$ enacted in 1925, requires courts to enforce pre-dispute arbitration agreements "save upon such grounds as exist at law or in equity for the revocation of any contract." ${ }^{2}$ Since the 1980s, the Supreme Court has repeatedly applied this requirement to predispute arbitration agreements in "contracts of adhesion,"3 the form contracts drafted by businesses and presented to consumers, employees, and others on a take-it-or-leave-it basis. ${ }^{4}$ Courts sometimes hold particular adhe-

19 U.S.C. $\S \S 1-16$ (2012). The FAA, originally called the United States Arbitration Act, was enacted in 1925.

${ }^{2} I d . \$ 2$ ("A written provision in any maritime transaction or a contract evidencing a transaction involving commerce to settle by arbitration a controversy thereafter arising out of such contract or transaction, or the refusal to perform the whole or any part thereof, or an agreement in writing to submit to arbitration an existing controversy arising out of such a contract, transaction, or refusal, shall be valid, irrevocable, and enforceable, save upon such grounds as exist at law or in equity for the revocation of any contract.").

${ }^{3}$ For the classic definition of "contract of adhesion," see Todd D. Rakoff, Contracts of Adhesion: An Essay in Reconstruction, 96 HARv. L. Rev. 1173, 1177 (1983). Some lawyers use the term "contract of adhesion" "to refer to a contract that is not only adhesive but also grossly unfair. This misuse of the term creates confusion. Probably most contracts of adhesion are simple and reasonable." Joseph M. Perillo, Calamari and Perillo on Contracts $\S 9.43$, at 348 n.3 (6th ed. 2009).

${ }^{4}$ See infra Part II, notes 42-46. 
sive arbitration agreements unenforceable on grounds, such as unconscionability, "for the revocation of any contract." Most cases, however, find no such ground applicable. Thus, they enforce the adhesion contract, requiring arbitration rather than litigation between the parties. ${ }^{5}$ For decades now, federal and state courts have applied the Supreme Court's interpretation of the FAA to enforce a wide variety of adhesive arbitration agreements in consumer, employment, and other contracts. ${ }^{6}$

This widespread enforcement of adhesive arbitration agreements is divisive, largely along predictable political lines. The FAA—originally drafted by counsel to the New York Chamber of Commerce ${ }^{7}$ - was enacted in a conservative era nearly a century ago. President Coolidge captured the spirit of the times when he said "[t]he business of America is business." ${ }^{\text {" Current }}$ defenders of the FAA, including its application to adhesion contracts, tend to be business-oriented conservatives. ${ }^{9}$ In contrast, proposals to regulate more

${ }^{5}$ See, e.g., Richard Frankel, The Arbitration Clause As Super Contract, 91 WASH. U. L. REv. 531, 529-33 (2014) ("Courts . . . have turned arbitration clauses into a type of "super contract.' Although courts purport to apply general contract law when interpreting arbitration clauses, they have in fact distorted contract law by creating special rules for arbitration clauses that make them enforceable in situations where other contracts are not."); Susan Landrum, Much Ado About Nothing?: What the Numbers Tell Us About How State Courts Apply the Unconscionability Doctrine to Arbitration Agreements, 97 MARQ. L. REv. 751, 755-56 (2014) ("[S]ome legal scholars have evaluated state courts' application of the unconscionability doctrine to arbitration agreements and have come to the conclusion that courts still often apply unconscionability in a way that demonstrates hostility to arbitration. . . [H] owever, such an approach may have the tendency to focus on outliers that are not necessarily representative."); Amy J. Schmitz, Mobile-Home Mania? Protecting Procedurally Fair Arbitration in a Consumer Microcosm, 20 Oніо ST. J. ON Disp. Resol. 291, 348 (2005) ("The problem remains that contract defenses have neither effectively nor efficiently policed the fairness of arbitration agreements. . . . Courts do not consistently apply contract defenses to ensure the consensual nature or fairness of $\mathrm{MH}$ and other consumer arbitration provisions."); Paul Weitzel, The End of Shareholder Litigation? Allowing Shareholders to Customize Enforcement Through Arbitration Provisions in Charters and Bylaws, 2013 BYU L. REv. 65, 111-12 (2013) ("Once a court finds an agreement to arbitrate, that agreement must be 'rigorously enforced,' and 'any doubts concerning the scope of arbitrable issues should be resolved in favor of arbitration, whether the problem at hand is the construction of the contract language itself or an allegation of waiver, delay, or a like defense to arbitrability.' This strong policy favoring arbitration will make it difficult for any defense to succeed.").

${ }^{6}$ Under the Supreme Court's interpretations of the United States Constitution's Commerce Clause and the FAA, the FAA's preemption of inconsistent state law leaves little room for state courts to enforce state law opposing enforcement of adhesive arbitration agreements. See generally Doctor's Assocs. v. Casarotto, 517 U.S. 681 (1996); Southland Corp. v. Keating, 482 U.S. 483 (1984); Allied-Bruce Terminix Cos. v. Dobson, 513 U.S. 265 (1995).

${ }^{7}$ Ian R. Macneil, American Arbitration Law: Reformation, Nationalization, InTernationalization 15 (1992); Christopher R. Drahozal, In Defense of Southland: Reexamining the Legislative History of the Federal Arbitration Act, 78 Notre Dame L. Rev. 101, 130 (2002) ("The author of the first draft of the FAA was Julius Henry Cohen, general counsel for the New York Chamber of Commerce and member of the ABA Committee on Commerce, Trade and Commercial Law.").

${ }^{8}$ John Steele Gordon, The Business of America 247 (2002).

${ }^{9}$ See infra Part II. 
tightly or even ban adhesive arbitration agreements tend to be supported by progressives. ${ }^{10}$

In recent years, opponents of adhesive arbitration agreements have enjoyed partial success by persuading Congress to enact several exceptions to the FAA's enforcement of them. ${ }^{11}$ For example, the Dodd-Frank Act of 2010 prohibited pre-dispute arbitration agreements in residential mortgages and home-equity loans. ${ }^{12}$ More broadly, Dodd-Frank also created a new federal agency, the Consumer Financial Protection Bureau ("CFPB"), ${ }^{13}$ and authorized it to "prohibit or impose conditions or limitations on the use of" predispute arbitration agreements in all consumer financial services contracts. ${ }^{14}$

Consequently, all three branches of the federal government now have significant power with respect to the law governing adhesive arbitration agreements: Congress could create further exceptions to the FAA, amend it, or even repeal it; the Supreme Court could amend or reverse its interpretations of the FAA; and the CFPB could promulgate regulations that exempt many consumer transactions from the FAA's enforcement of pre-dispute arbitration agreements. Though any of these major changes is quite possible in the next few years, the third seems most likely, because conservatives or Republicans currently comprise majorities in both houses of Congress, while the CFPB is directed by a Democrat appointed by the President who signed the Dodd-Frank Act. ${ }^{15}$ Moreover, early indications suggest the CFPB is likely "to either ban or to severely limit arbitration provisions in consumer

${ }^{10}$ See id.

${ }^{11}$ See, e.g., Department of Defense Appropriations Act, 2010, Pub. L. No. 111-118, $\S$ 816(a), 123 Stat. 3409 (2009) (prohibiting defense contractors from including arbitration clauses in employment contracts).

12 The Dodd-Frank Wall Street Reform and Consumer Protection Act of 2010, Pub. L. No. 111-203, § 1414(e), 124 Stat. 1964 (2010) ("No residential mortgage loan and no extension of credit under an open end consumer credit plan secured by the principal dwelling of the consumer may include terms which require arbitration or any other nonjudicial procedure as the method for resolving any controversy or settling any claims arising out of the transaction.").

${ }^{13}$ Creating the Consumer Bureau, Consumer Fin. Protection Bureau, http://www.consumerfinance.gov/the-bureau/creatingthebureau/ [perma.cc/7FGH-VP3X]. The Bureau is an independent agency that operates under a director appointed by the President with Senate consent; it has investigatory, rulemaking, and enforcement powers. 12 U.S.C. $\$ \S 5491$ (a)-(c), 5492(a) (2012).

${ }^{14} 12$ U.S.C. $\$ \$ 5518(\mathrm{a})-(\mathrm{c})$ (2012); see also CFPB Launches Public Inquiry into Arbitration Clauses, Consumer Fin. Protection Bureau (Apr. 24, 2012), http://www.consumerfinance.gov/newsroom/consumer-financial-protection-bureau-launches-public-inquiryinto-arbitration-clauses/ [perma.cc/J2H4-UHPJ]; The Dodd-Frank Wall Street Reform and Consumer Protection Act of 2010, Pub. L. No. 111-203, 124 Stat. 1964 (2010) (codified at 12 U.S.C. $\$ \S 5301-5587$ and miscellaneous provisions).

15158 Cong. Rec. E1419, 1420 (daily ed. Aug. 3, 2012) (statement of Rep. Kaptur) (“Attorney General Richard Cordray, a Democrat . . .."); Arthur E. Wilmarth, Jr., Reregulation \& the Business Firm Symposium: Financial Institutions: The Dodd-Frank Act's Expansion of State Authority to Protect Consumers of Financial Services, 36 IowA J. CorP. L. 893, 895 (2011) ("On July 21, 2010, President Barack Obama signed into law the Dodd-Frank Wall Street Reform and Consumer Protection Act."). 
financial service contracts." 16 So while this Article's reasoning and proposals for reform are written for Congress and the Supreme Court as much as for the CFPB, this Article also offers the CFPB the language of a rule that the CFPB could enact to accomplish the reforms proposed in this Article. ${ }^{17}$

These proposed reforms are politically centrist. As noted above, the current widespread enforcement of adhesive arbitration agreements tends to be supported by conservatives while proposals to regulate more tightly or even ban adhesive arbitration agreements tend to be advocated by progressives. ${ }^{18}$ This ideological divide fits a century-long pattern in which regulation of consumer, employment, and other adhesive contract terms is advocated by progressives who tend to see such regulation as protecting vulnerable people from rapacious businesses, rather than by conservatives who tend to see regulation of adhesion contract terms as raising costs to, and restricting the freedom of, both parties to the contract. ${ }^{19}$ Because in the United States adhesion contracts often implicate one's political philosophy, disagreements about them can be profound. Such disagreements are not compromised easily and finding a moderate middle ground acceptable to both sides is a difficult task. With respect to adhesive arbitration agreements, this Article undertakes that difficult task.

${ }^{16}$ Christine A. Scheuneman, Amy L. Pierce \& Joseph T. Lynyak, III, CFPB's Arbitration Study-A Warning to Consumer Financial Service Companies, Pillsbury Law (Jan. 8, 2014), http://www.pillsburylaw.com/publications/cfpbs-arbitration-study-a-warning-to-consumer-financial-service-companies [perma.cc/Y5SS-XDUG]. The CFPB issued a report in March 2015. See Consumer Fin. Prot. Bureau, Arbitration Study: Report to Congress, pursuant to Dodd-Frank Wall Street Reform and Consumer Protection Act § 1028(a) (Mar. 2015), http://files.consumerfinance.gov/f/201503_cfpb_arbitration-study-report-to-congress-2015.pdf [perma.cc/NXC5-726F]. Reactions to the CFPB report anticipate regulation or even prohibition of many consumer pre-dispute arbitration agreements. See The Trial Lawyer Financial Protection Bureau?, U.S. Chamber Com., Inst. For Legal Reform (Mar. 11, 2015), http://www.instituteforlegalreform.com/resource/the-trial-lawyer-financial-protectionbureau- [perma.cc/688K-N4K2] ("The [CFPB] report on arbitration released this week has one very clear conclusion: litigation is better than arbitration. This raises the question of whether the exercise has been less about protecting consumers and more about helping the plaintiffs' lawyers.”); David F. Freeman, Jr. et al., CFPB Releases Much Anticipated Arbitration Clause Study, ARnold \& PoRTer LLP (Mar. 2015), http://www.arnoldporter.com/resources/documents/ADV13Mar2015CFPBReleasesMuchAnticipatedArbitrationClauseStudy .pdf [perma.cc/U488-E5B9] ("In our view, the CFPB's report foreshadows potential regulation of arbitration clauses in contracts for consumer financial products and services."); Eric Mills \& Joshua Davey, CFPB Releases Study on Use of Arbitration Clauses in Consumer Contracts, SubJect to InQuiry (Mar. 20, 2015), http://www.subjecttoinquiry.com/cfpb/cfpbreleases-study-on-use-of-arbitration-clauses-in-consumer-contracts/ [perma.cc/RNU9-2YS9] (" $[\mathrm{I}] \mathrm{t}$ seems nearly certain that the CFPB will attempt to restrict the use of arbitration requirements in consumer contracts."); Nancy Thomas \& James McGuire, CFPB Releases Arbitration Study Report to Congress, Morrison Foerster Enforcement Blog (Mar. 12, 2015), http:// www.moforeenforcement.com/2015/03/cfpb-releases-arbitration-study-report-to-congress/ [perma.cc/FJH9-LU6J] ("[T]he CFPB's report lays the groundwork for the CFPB to issue regulations prohibiting or limiting the use of such clauses.").

${ }^{17}$ See infra Part V.

${ }^{18}$ See infra Part II.

${ }^{19}$ See infra Part II \& note 75. 
This Article begins with a plea that progressives and conservatives acknowledge two truths in the phrase "adhesion contracts" and accept that arbitration law should reconcile these two truths in much the same way our law as a whole does. The two truths in the phrase "adhesion contracts" are (1) that they are contracts and (2) they are adhesive, drafted by businesses and presented to consumers, employees, and other adhering parties on a take-it-or-leave-it basis. Both of these truths are deeply woven into federal and state law. Adhesion contracts are contracts, because most of their terms are routinely enforced by courts throughout the country. ${ }^{20}$ On the other hand, the fact that adhesion contracts are adhesive typically raises courts' readiness to deny enforcement to some of their terms on contract-law grounds like unconscionability. ${ }^{21}$ And legislatures' widespread sense that courts need help policing the terms of adhesion contracts leads to the enactment of many statutes and regulations prohibiting various terms that were previously found in adhesion contracts. ${ }^{22}$ Indeed the entire body of consumer law consists largely of statutes and regulations prohibiting various adhesion contract

${ }^{20}$ See, e.g., Gatton v. T-Mobile USA, Inc., 61 Cal. Rptr. 3d 344, 355 (Cal. Ct. App. 2007) ("[C]ontracts of adhesion are well accepted in the law and routinely enforced . . .."); RESTATEMENT (SECOND) OF Contracts $\$ 211 \mathrm{cmt}$. a (1981) ("Standardization of agreements serves many of the same functions as standardization of goods and services; both are essential to a system of mass production and distribution."); Tom W. Bell, Graduated Consent in Contract and Tort Law: Toward A Theory of Justification, 61 CASE W. REs. L. REv. 17, 50 (2010) (" $[\mathrm{M}]$ ost courts, regard even take-it-or-leave-it, standard form agreements, formed between powerful legal entities and relatively powerless natural persons, as not only prima facie valid, but moreover as boons for social utility."); Steven J. Burton, The New Judicial Hostility to Arbitration: Federal Preemption, Contract Unconscionability, and Agreements to Arbitrate, 2006 J. Disp. Resol. 469, 479 (2006) (stating that "[a]dhesion contracts are ubiquitous" and "generally are enforced"); Juliet M. Moringiello, Signals, Assent and Internet Contracting, 57 Rutgers L. REv. 1307, 1314-15 (2005) (“[C]ourts routinely enforce standard form contracts unless they give no notice of the fact that they contain terms that could affect the offeree's legal rights, or contain unconscionable or objectively unexpected terms."); Raymond T. Nimmer, Breaking Barriers: The Relation Between Contract and Intellectual Property Law, 13 Berkeley TeCH. L.J. 827, 848 (1998) ("Contracts of adhesion are routinely enforced. A contract of adhesion analysis typically indicates that a court enforces the contract, but scrutinizes its terms more closely for terms that are procedurally or substantively unconscionable.").

${ }^{21}$ Russell Korobkin, Bounded Rationality, Standard Form Contracts, and Unconscionability, 70 U. CHI. L. Rev. 1203, 1258 (2003) ("In some cases, courts point to the adhesive nature of form contracts as evidence that the terms therein are 'involuntary' and thus procedurally unconscionable."); id. at 1295 n.201 ("The majority of courts, however, find that the fact that a contract is adhesive is not alone enough for a finding of procedural unconscionability."); Catherine Riley, Signing in Glitter or Blood?: Unconscionability and Reality Television Contracts, 3 N.Y.U. J. InTell. Prop. \& ENT. L. 106, 120 (2013) ("Habitually, courts assume procedural unconscionability in contracts of adhesion . . .."); Edith R. Warkentine, Beyond Unconscionability: The Case for Using "Knowing Assent" As the Basis for Analyzing Unbargained-for Terms in Standard Form Contracts, 31 Seattle U. L. Rev. 469, 547 (2008) (noting that California courts "equate the finding of a contract of adhesion with the finding of procedural unconscionability").

${ }^{22}$ Max Helveston \& Michael Jacobs, The Incoherent Role of Bargaining Power in Contract Law, 49 WAKe Forest L. Rev. 1017, 1054 (2014) ("Examples abound of laws and regulations aimed at resolving the very concerns that have led courts to turn to bargainingpower analysis. In a number of different areas, legislatures and agencies have prohibited contracts from including terms deemed abusive to one of the parties."). 
terms, ${ }^{23}$ as do fundamental doctrines of employment, ${ }^{24}$ labor, ${ }^{25}$ securities, ${ }^{26}$ and franchise law. ${ }^{27}$ The enormous growth over the last hundred years of such legislation and agency rules regulating business is to a large extent the result of policymakers' decisions to prohibit enforcement of adhesive contract terms that would have been enforced had unconscionability and other contract-law doctrines been the only grounds on which to deny enforcement.

With the two truths in the phrase "adhesion contracts"- that they are contracts, but also adhesive-firmly in mind, this Article's basic premise is that adhesive arbitration agreements should be treated like other adhesion contracts. Because adhesion contracts generally are at least presumptively enforceable in our law, so should adhesive arbitration agreements be at least presumptively enforceable, ${ }^{28}$ and because adhesion contracts are generally limited by our law, so adhesive arbitration agreements should be similarly limited. After decades engaged in scholarly, policy, and litigation debates about adhesive arbitration agreements, ${ }^{29}$ I have concluded that three of U.S. (state and federal) law's general limits on adhesion contracts are especially pertinent to adhesive arbitration agreements.

(1) Because U.S. law generally only enforces adhesion contracts after allowing the party opposing enforcement to argue contract-law defenses to enforcement (such as unconscionability and misrepresentation), adhesive arbitration agreements should only be enforced

${ }^{23}$ Id. at 1054-55 ("State usury laws limit the amount of interest that lenders can charge to certain types of borrowers. The Federal Trade Commission ('FTC') has issued regulations dictating terms that must, and must not, be included in payday loans, credit card agreements, and other consumer-oriented financial contracts.").

${ }^{24} I d$. at 1055 ("The Occupational Safety and Health Act and minimum wage laws establish mandatory requirements for employment contracts.").

${ }^{25}$ An employee's right to join a labor union may not be contracted away pre-dispute; socalled "yellow dog" contracts are unenforceable under federal labor law. 29 U.S.C. § 103 (2012); Phelps Dodge Corp. v. NLRB, 313 U.S. 177, 187 (1941).

${ }^{26}$ See 15 U.S.C. $\$ 77 \mathrm{n}$ (2012) (Securities Act anti-waiver provision); 15 U.S.C. $§ 77 \mathrm{cc}$ (a) (2012) (Securities Exchange Act anti-waiver provision: "Any condition, stipulation, or provision binding any person to waive compliance with any provision of this chapter or of any rule or regulation thereunder, or of any rule of a self-regulatory organization, shall be void.").

${ }^{27}$ Robert W. Emerson, Franchising and the Parol Evidence Rule, 50 Am. Bus. L.J. 659, 680-81 (2013) (" $[\mathrm{M}]$ ost state statutes regulating franchise relationships prohibit franchisors from requiring their franchisees to waive the franchisor's liability for a violation of those state franchise laws when entering into a franchise agreement."); Daniel B. Kelly, The Right to Include, 63 EMORY L.J. 857, 912 (2014) ("Although similar to contracts, franchises differ because franchise law entails certain mandatory rules (e.g., limitations on termination) and attempts to deter renegotiation in ways that contract law generally does not.").

${ }^{28}$ See infra Part III.E \& note 152.

${ }^{29}$ My experience in these debates includes testimony as an expert witness in court and before both houses of Congress, as well as many academic symposia and law review articles, and two books, including one in which I and three co-authors debated possible amendments to the FAa. See Edward Brunet, Richard E. Speidel, Jean R. Sternlight \& Stephen J. Ware, Arbitration Law in America: A Critical Assessment (2006). 
after allowing the party opposing enforcement to argue contractlaw defenses to enforcement; ${ }^{30}$

(2) Because U.S. law generally does not enforce adhesion contract terms prohibiting appeal and thus trading away the right to correct legally-erroneous decisions on certain claims, courts should not enforce adhesive arbitration agreements trading away that right; ${ }^{31}$ and

(3) Because U.S. law generally does not routinely enforce adhesion contract terms "waiving" - actually trading away ${ }^{32}$ - the right to be a part of a class action, courts should not routinely enforce adhesive arbitration agreements trading away the right to be a part of a class action. ${ }^{33}$

In sum, the fact that an adhesion contract contains an arbitration clause should not, on these three topics, make it more or less enforceable than the same contract would be without an arbitration clause. With few and relatively uncontroversial exceptions, ${ }^{34}$ adhesive arbitration agreements should be enforced no more broadly or readily than other adhesion contracts.

Part II of this Article provides a history of how current law governing adhesive arbitration agreements developed and became divisive along predictable political lines. Part III introduces a framework to understand and compare different views about the law governing adhesive arbitration agreements. Basically, the views can be arrayed on a continuum about the level of consent the law should require before enforcing an arbitration agreement against an individual, such as a consumer or employee. Progressives generally would require higher levels of consent than arbitration law currently requires, while conservatives generally defend current arbitration law's low standards of consent.

Part IV proposes an intermediate (or centrist) position. It joins progressives in rejecting conservative-supported anomalies that enforce adhesive arbitration agreements more broadly than other adhesion contracts on the three specific issues noted above: contract-law defenses; correcting legally-erroneous decisions; and class actions. Once these anomalies are fixed though, adhesive arbitration agreements should - contrary to the progressive position-be as generally enforceable as other adhesion contracts. In other words, this Article joins conservatives in defending general enforcement of adhesive arbitration agreements under contract law's standards of consent. Part V briefly concludes. Finally, this Article includes an appendix with the language of a rule the CFPB could adopt to enact into law the reforms advocated in this Article.

\footnotetext{
${ }^{30}$ See infra Part III.F \& note 153.

${ }^{31}$ See infra Part III.G.i \& note 154.

${ }^{32}$ See infra note 139.

${ }^{33}$ See infra Part III.G.ii \& note 155.

${ }^{34}$ See infra note 133 (discussing discovery, evidence, and jury).
} 


\section{The Political Divide Over Law Governing Adhesive Arbitration Agreements}

Current law's enforcement of adhesive arbitration agreements tends to be supported by the Right (conservatives) and opposed by the Left (progressives). For example, the last Congress's broadest bill to end enforcement of adhesive arbitration agreements, the Arbitration Fairness Act, had twentyfour co-sponsors in the Senate, none of whom were Republicans. ${ }^{35}$ Supporters of this bill, versions of which have been introduced in many congresses, ${ }^{36}$ include generally progressive groups such as the AFL-CIO, ACLU, Alliance for Justice, American Association for Justice (formerly American Trial Lawyers Association), NAACP, and Public Citizen, ${ }^{37}$ while opponents of this bill include generally conservative business-oriented groups such as the U.S. Chamber of Commerce, National Association of Manufacturers, and American Bankers Association. ${ }^{38}$ The interest-group battle over adhesive arbitra-

${ }^{35}$ Arbitration Fairness Act of 2013, S. 878, 113th Cong. (2013).

${ }^{36}$ See Arbitration Fairness Act of 2013, H.R. 1844, 113th Cong. (2013); Arbitration Fairness Act of 2013, S. 878, 113th Cong. (2013); Arbitration Fairness Act of 2011, H.R. 1873, 112th Cong. (2011); Arbitration Fairness Act of 2011, S. 987, 112th Cong. (2011); Arbitration Fairness Act of 2009, S. 931, 111th Cong. (2009); Arbitration Fairness Act of 2009, H.R. 1020, 111th Cong. (2009); Arbitration Fairness Act of 2007, H.R. 3010, 110th Cong. (2007); Arbitration Fairness Act of 2007, S. 1782, 110th Cong. (2007); Arbitration Fairness Act of 2002, S. 3026, 107th Cong. (2002).

${ }^{37}$ Re: Support for the Arbitration Fairness Act of 2013, S. 878, Public Citizen (Dec. 16, 2013), http://www.citizen.org/documents/organizations-letter-judiciary-committee-arbitrationfairness-act-2013.pdf [perma.cc/5PQ4-6D69]. The full list of organizations signing this letter: 9to5, AARP, AFL-CIO, Alliance for Justice, American Association for Justice, American Association of University Women, American Civil Liberties Union (ACLU), American Federation of State, County and Municipal Employees (AFSCME), AFL-CIO, Americans for Financial Reform, Bazelon Center for Mental Health Law, Center for Justice \& Democracy, Center for Responsible Lending, Citizen Works, Committee to Support the Antitrust Laws, Consumer Action, Consumer Federation of America, Consumer Watchdog, Consumers for Auto Reliability and Safety, Consumers Union, ConsumersCount.org, D.C. Consumer Rights Coalition, Home Owners for Better Building, Homeowners Against Deficient Dwellings, Legal Aid Justice Center, Maryland Consumer Rights Coalition, MFY Legal Services, Inc., NAACP, National Association of Consumer Advocates, National Consumer Voice for Quality Long-Term Care, National Consumer Law Center, National Consumers League, National Employment Law Project, National Employment Lawyers Association (NELA), National Partnership for Women \& Families, National Women's Law Center, NC Justice Center, People For the American Way, Public Citizen, Reserve Officers Association (ROA), The Leadership Conference on Civil and Human Rights, U.S. Public Interest Research Group, West Virginia Citizen Action Group.

${ }^{38}$ Multi-Industry Letter Opposing the Onslaught of Anti-Arbitration Bills and Provisions That Have Been Introduced in this Congress, U.S. CHAMBER of CoM. (Apr. 30, 2008), https:// www.uschamber.com/letter/multi-industry-letter-opposing-onslaught-anti-arbitration-billsand-provisions-have-been [perma.cc/KJ6J-KQ3B]; see also Richard Gibson, Arbitration Holds Steady for Franchising Disputes, WaLl St. J. (June 1, 2009), http://online.wsj.com/ news/articles/SB124388471631873317 [perma.cc/8NSB-ZD4Q] ("The International Franchise Association, franchisers' primary trade organization, opposes the [2009 Arbitration Fairness Act] bill, contending that it would "wreak havoc on a long-standing and effective form of alternative dispute resolution."); Lobby Spending Database for the U.S. Chamber of Commerce for 2013, Specific Issue: Torts, OpenSECRETs.org, https://www.opensecrets.org/ lobby/clientissues_spec.php?id $=$ D000019798\&year $=2013 \&$ spec $=$ TOR $\quad[p e r m a . c c / A 6 P S-$ 
tion agreements basically pits businesses against those who sue them, with plaintiffs' lawyers ${ }^{39}$ and law professors who had been plaintiffs' lawyers leading the research and arguments against adhesive arbitration agreements. ${ }^{40}$ In the legislative arena, as well as in courtrooms around the country, the "plaintiffs" lawyers versus business" battle over adhesive arbitration agreements has raged since the 1990s. ${ }^{41}$

The conservative/progressive divide in Congress and among interest groups corresponds to the conservative/progressive divide on the Supreme Court. The four most recent Supreme Court cases of great importance to adhesive arbitration agreements show a highly partisan voting pattern. Two of these cases, American Express Co. v. Italian Colors Restaurant ${ }^{42}$ and $A T \& T$ Mobility LLC v. Concepcion, ${ }^{43}$ split the Court along completely partisan lines with all five justices appointed by Republican presidents voting to enforce the adhesive arbitration agreements, while all four justices appointed by Democratic presidents voted against enforcement. ${ }^{44}$ The same was true of Rent-A-Center, West, Inc. v. Jackson ${ }^{45}$ except that the four dissenters consisted of the three Democratic-appointees then on the Court plus Justice Stevens, who was appointed by President Ford-perhaps the last Republican president who would not be considered solidly conservative today. So RentA-Center seems to have split the Court along completely ideological lines.

7DH2]; Who Really Speaks for Consumers in the Arbitration Debate?, U.S. Chamber of Com., Inst. FOR Legal ReForm (Aug. 28, 2009), http://www.instituteforlegalreform.com/resource/who-really-speaks-for-consumers-in-the-arbitration-debate/ [perma.cc/YN3G-7PJT].

${ }^{39}$ See Tom Osborne \& John Vail, The Menace of Mandatory Arbitration, Trial, Aug. 2004, at 22; Jeffrey Robert White, Mandatory Arbitration: A Growing Threat, TRIAL, July 1999, at 32; F. Paul Bland, Jr. \& Michael J. Quirk, Securing Access to Justice, Trial Laws. FOR PUB. JUST. (2002), http://www.hiddenmysteries.org/money/aids/Mandatory_Arbitration .pdf [perma.cc/5QQE-EDP3]; Paul Bland, Arbitrators are Answerable to No One, PuB. CITIZEN CONSUMER L. \& POL'Y BloG (Oct. 19, 2006, 8:14 AM), http://pubcit.typepad.com/clpblog/2006/10/arbitrators_are.html [perma.cc/6SKJ-3LCR].

${ }^{40}$ See, e.g., Paul Carrington, The Dark Side of Contract Law, Trial, May 2000, at 73, 77 (referring to "examples of how forced arbitration can hurt workers, consumers, and victims, which can be used in educating the public and others about abuse of arbitration"); Jean R. Sternlight, Mandatory Binding Arbitration Clauses Prevent Consumers from Presenting Procedurally Difficult Claims, 42 Sw. L. Rev. 87, 108 (2012); Jean R. Sternlight, Tsunami: AT\&T Mobility v. Concepcion Impedes Access to Justice, 90 Or. L. Rev. 703, 722-23 (2012). See generally Jean R. Sternlight, Mandatory Binding Arbitration and the Demise of the Seventh Amendment Right to a Jury Trial, 16 Oнiо St. J. on DisP. Resol. 669 (2001); Jean R. Sternlight, Rethinking the Constitutionality of the Supreme Court's Preference for Binding Arbitration: A Fresh Assessment of Jury Trial, Separation of Powers, and Due Process Concerns, 72 Tul. L. Rev. 1 (1997); Jean R. Sternlight, Panacea or Corporate Tool?: Debunking the Supreme Court's Preference for Binding Arbitration, 74 WASH. U. L. Q. 637 (1996).

${ }^{41}$ Stephen J. Ware, The Alabama Story, Disp. Resol. MAg., Summer 2001, at 24.

42133 S. Ct. 2304 (2013).

43131 S. Ct. 1740 (2011).

${ }^{44}$ See Italian Colors, 133 S. Ct. at 2304, 2313 (Scalia, J., writing majority opinion; Thomas, J., concurring; Kagan, J., dissenting, joined by Breyer and Ginsburg, JJ.); Concepcion, 131 S. Ct. at 1740, 1753 (Scalia, J., writing majority opinion; Thomas, J., concurring; Breyer, J., dissenting joined by Ginsburg, Sotomayor, and Kagan, JJ.).

${ }^{45} 561$ U.S. 63 (2010). 
Similarly, in CompuCredit Corp. v. Greenwood, ${ }^{46}$ the only dissenter from enforcement of the adhesive arbitration agreement was a Democratic-appointee (Justice Ginsburg) and two of the other three Democratic-appointees (Justices Sotomayor and Kagan) wrote a separate concurring opinion saying "for the reasons stated by the dissent, I find this to be a much closer case than the majority opinion suggests." ${ }^{47}$ In short, the Supreme Court justices have divided along almost completely partisan lines, and perhaps completely ideological lines, throughout the last four cases which are most important to adhesive arbitration agreements. ${ }^{48}$

In contrast to this recent partisan or ideological voting on the Court, many of the earlier Supreme Court decisions important to adhesive arbitration agreements had pro-enforcement majorities consisting of at least seven justices, including at least half of the justices appointed by Democratic presidents. ${ }^{49}$ These cases, stretching from 1984 to 2006, are:

\section{Southland Corp. v. Keating, ${ }^{50}$}

${ }^{46} 132$ S. Ct. 665 (2012).

${ }^{47} I d$. at 675 (Sotomayor, J., concurring).

${ }^{48}$ The most important of the less important cases is probably DIRECTV, Inc. v. Imburgia, 136 S. Ct. 463 (2015) (reiterating Concepcion while overturning the California court's arguably stretching contract interpretation in attempt to avoid Concepcion), in which justices appointed by Democratic presidents split, while all justices appointed by Republican presidents joined the majority, except for Justice Thomas who reliably dissents from holdings that the FAA preempts state law.

A still less important case is Marmet Health Care Ctr., Inc. v. Brown, 132 S. Ct. 1201 (2012) (per curiam), which addressed no important new issues and merely corrected lower court error about long-established law. See Christopher R. Drahozal, Error Correction and the Supreme Court's Arbitration Docket, 29 Oніо Sт. J. on Disp. Resol. 1, 11 (2014) ("The West Virginia Supreme Court of Appeals in Marmet Health Care Center, Inc. v. Brown had created an exception to the FAA that was nowhere in the text of the statute and that wholly lacked support in any prior Supreme Court precedent."); id. (describing the West Virginia court's decision, overturned per curiam by the Supreme Court, as a "direct attack[ ] on the reasoning of Supreme Court arbitration decisions" and "blatant"); Brown v. Genesis Healthcare Corp., 724 S.E.2d 250 (W. Va. 2011), rev'd sub nom. Marmet Health Care Ctr., Inc. v. Brown, 132 S. Ct. 1201 (2012) (per curiam).

Another unimportant case (because it addressed no important new issues and merely corrected lower court error about long-established law) is Nitro-Lift Technologies, L.L.C. v. Howard, 133 S. Ct. 500 (2012) (per curiam). See Drahozal, supra, at 11 ("The Oklahoma decision in Nitro-Lift Technologies, LLC v. Howard was flatly contrary to Buckeye Check Cashing, Inc. v. Cardegna, in which the Supreme Court held that the arbitrator, rather than a court, is to decide whether the main contract (i.e., the contract that includes the arbitration clause) is illegal.").

${ }^{49}$ The one significant exception to this, and perhaps a precursor to the Court's recent partisan or ideological arbitration voting, was a consumer arbitration case, Green Tree Fin. Corp.-Alabama v. Randolph, 531 U.S. 79 (2000), in which the pro-enforcement majority consisted of five Republican appointees while the four dissenters consisted of the two Democratic appointees then on the Court plus Justice Stevens and Justice Souter, who was appointed by the first President Bush.

50465 U.S. 1 (1984) (holding that FAA requires state court to compel arbitration of claim despite state law to the contrary). Republican appointees in majority: Burger (author), Blackmun, Brennan, and Powell; Democratic appointees in majority: Marshall and White. 
2. Perry v. Thomas, ${ }^{51}$

3. Gilmer v. Interstate/Johnson Lane Corp. ${ }^{52}$

4. Allied-Bruce Terminix Companies, Inc. v. Dobson, ${ }^{53}$

5. Doctor's Associates, Inc. v. Casarotto, ${ }^{54}$ and

6. Buckeye Check Cashing, Inc. v. Cardegna. ${ }^{55}$

These decisions by broad pro-enforcement majorities on the Court, from 1984 to 2006, produced enormous changes to arbitration law, especially to the law governing adhesive arbitration agreements. Prior to 1984, such agreements were generally unenforceable, or at least unenforceable with respect to many statutory claims. ${ }^{56}$ In contrast, by 2006 adhesive arbitration agreements were routinely enforced with respect to all claims. ${ }^{57}$ So the Supreme Court from 1984 to 2006 made major decisions to enforce adhesive arbitration agreements, and it did so with substantial support from Democratic-appointed justices. In fact, the majority opinions in four of the six cases just listed (Perry, Gilmer, Allied-Bruce, and Doctor's Associates) were authored by Democratic-appointed justices.

This study of the justices' votes suggests two conclusions. First, as big as the Court's 1984-2006 changes to adhesive arbitration law were, those changes were not far out of step with the political center of that era. While those Supreme Court decisions were criticized in plaintiffs' lawyers' journals, and by like-minded academics, ${ }^{58}$ such criticism did not persuade newly appointed justices (including Democratic-appointed Justices Ginsburg and Breyer) to vote to undo what earlier-appointed justices had done. Nor did criticism of the Court's 1984-2006 change to enforcing adhesive arbitration agreements move Congress to undo by statute any large part of what the Court had done, although Congress did prohibit enforcement of pre-dispute

${ }^{51} 482$ U.S. 483 (1987). Republican appointees in majority: Rehnquist, Brennan, Blackmun, Powell, and Scalia; Democratic appointees in majority: Marshall (author) and White.

${ }^{52} 500$ U.S. 20 (1991) (enforcing adhesive arbitration agreement against employee seeking to sue employer). Republican appointees in majority: Rehnquist, Blackmun, O'Connor, Scalia, Kennedy, and Souter; Democratic appointees in majority: White (author). Marshall was the only other Democratic appointee on the Court.

53513 U.S. 265 (1995) (holding that FAA preemption of state law encompasses full scope of Constitution's Commerce Clause). Republican appointees in majority: Rehnquist, Stevens, O'Connor, Kennedy, and Souter; Democratic appointees in majority: Breyer (author) and Ginsburg.

${ }^{54} 517$ U.S. 681 (1996) (holding that FAA preempts state law requiring adhesive arbitration agreements to be on contract's first page and in large font). Republican appointees in majority: Rehnquist, Stevens, O'Connor, Scalia, Kennedy, and Souter; Democratic appointees in majority: Ginsburg (author) and Breyer.

${ }^{55} 546$ U.S. 440 (2006) (holding that FAA preempts state law ruling that consumer finance arbitration agreement was unenforceable due to usury). Republican appointees in majority: Scalia (author), Roberts, Stevens, Souter, and Kennedy; Democratic appointees in majority: Ginsburg and Breyer.

${ }^{56}$ Stephen J. Ware, Principles of Alternative Dispute Resolution $\$$ 2.6-2.14, 2.27-2.28 ( $2 \mathrm{~d}$ ed. 2007).

${ }^{57} \mathrm{Id}$.

${ }^{58}$ See supra notes $39-40$. 
arbitration agreements in two very narrow situations: motor vehicle franchise agreements between automobile manufacturers and dealers, ${ }^{59}$ and the credit agreements of military personnel. ${ }^{60}$ In sum, the Supreme Court's 1984-2006 decisions may have pushed arbitration law_including law on adhesive arbitration agreements - a bit to the right of center, but apparently not very far right of center.

In contrast, the current Supreme Court's Republican-appointed justices now seem farther from the political center on law governing adhesive arbitration agreements. This is the second conclusion suggested by the above study of the justices' votes. As noted above, the last four cases important to adhesive arbitration agreements have divided the justices along almost completely partisan lines and perhaps completely ideological lines, without the broad bipartisan support (from Democratic-appointed justices) enjoyed by earlier decisions enforcing adhesive arbitration agreements. ${ }^{61}$ In addition, the nation's political center itself probably moved left after 2006, at least with respect to the area of law most focused on adhesion contracts-consumer law. While 2006 began with a Republican president and Republican majorities in both houses of Congress, the years immediately following 2006 included the financial crisis and the Great Recession ${ }^{62}$ (both of which were widely blamed on lenders exploiting consumers ${ }^{63}$ ), the election of President Obama, and the Dodd-Frank Act, ${ }^{64}$ which may have been the single biggest

${ }^{59} 15$ U.S.C. $\S 1226(a)(2)$ (2012) ("Notwithstanding any other provision of law, whenever a motor vehicle franchise contract provides for the use of arbitration to resolve a controversy arising out of or relating to such contract, arbitration may be used to settle such controversy only if after such controversy arises all parties to such controversy consent in writing to use arbitration to settle such controversy.").

${ }^{60} 10$ U.S.C. § 987(f)(4) (2012) ("Notwithstanding section 2 of title 9, or any other Federal or State law, rule, or regulation, no agreement to arbitrate any dispute involving the extension of consumer credit shall be enforceable against any covered member or dependent of such a member, or any person who was a covered member or dependent of that member when the agreement was made.").

${ }^{61}$ See supra notes $42-57$.

${ }^{62}$ The financial crisis is often dated around the 2008 bankruptcy of Lehman Brothers. 2008 to 2013: Crisis, Recovery, and Change, Bloomberg Businessweek (2013), http://www .businessweek.com/features/financial-crisis-anniversary-2013/ [https://perma.cc/52MHBM4E]; see also Marketplace Staff, Lehman's Legacy: A Timeline of How the Financial Crisis Unfolded, MARKETPLACE.ORG (Sept. 11, 2013, 7:31 AM), http://www.marketplace.org/topics/ economy/after-lehman/lehman\%E2\%80\%99s-legacy-timeline-how-financial-crisis-unfolded [https://perma.cc/K85C-FSZ3]. The Great Recession lasted from December 2007 to June 2009. Business Cycle Dating Committee, National Bureau of Economic Research, NAT'L BuREAU OF ECON. RESEARCH (Sept. 20, 2010), http://www.nber.org/cycles/sept2010.html [https:/ /perma.cc/HZ6X-KXTR].

${ }^{63}$ Editorial, When a Car Loan Means Bankruptcy, N.Y. Times (Aug. 8, 2014), http://www .nytimes.com/2014/08/09/opinion/when-a-car-loan-means-bankruptcy.html [https://perma.cc/ JJ7A-KL4S] ("The mortgage industry set the stage for the recession by luring people into ruinously priced loans they could never hope to repay, then selling those loans to Wall Street in mortgage-backed securities that went bad."); Zachary A. Goldfarb \& Brady Dennis, Government Report Blames Regulators and Financial Institutions for Economic Crisis, WAsH. Post (Jan. 27, 2011), http://www.washingtonpost.com/wp-dyn/content/article/2011/01/27/AR 2011012702940.html [https://perma.cc/A2LJ-CBVQ].

${ }^{64}$ Pub. L. No. 111-203, 124 Stat. 1376 (2010). 
leftward movement of consumer law since at least the 1970s. ${ }^{65}$ With respect to consumer arbitration, the Dodd-Frank Act:

- generally banned the use of pre-dispute arbitration agreements in residential mortgages and home-equity loans; ${ }^{66}$

- prohibited enforcement of pre-dispute arbitration agreements in the context of certain whistleblowers; ${ }^{67}$ and

- created the Consumer Financial Protection Bureau ${ }^{68}$ and authorized it to "prohibit or impose conditions or limitations on the use of" predispute arbitration clauses in many consumer financial services contracts. ${ }^{69}$

The Democratic congress that passed Dodd-Frank also enacted a Defense Appropriations Act that prohibited large military appropriations to any contractor that requires its employees agree to arbitrate as a condition of employment. ${ }^{70}$

In sum, since 2006 the nation's political center on consumer law seems to have moved left while the Republican-appointed justices' decisions on adhesive arbitration agreements have continued moving right. This divergence would be reduced or perhaps eliminated if this Article's proposals were adopted. For that reason, I describe this Article's proposals as "centrist."

However, I do not advocate these proposals solely, or even primarily, because they would bring law governing adhesive arbitration agreements back toward the nation's political center. I do not believe this or any area of law should constantly seek the center, because that would require legal rules constantly to change with the direction of the prevailing political winds. Such change would be bad because stability is an important virtue in the law. But those who prudently value stability in the law should, like Edmund Burke, be as skeptical of the absence of legal change as of constant or rapid

${ }^{65}$ Douglas Whaley, Problems and Materials on Consumer Law, at xxiv (7th ed. 2013) (" $[I] n 2010$ a new phase of consumer law began, the most important since the 1960s. Congress passed the Dodd-Frank Wall Street Reform and Consumer Protection Act . . . and the existing rules underwent a tectonic shift. The need for Dodd-Frank arose from the Great Recession of 2008 when subprime lending collapsed the markets and millions of people were thrown out of work."); Viral Acharya et al., A Critical Assessment of the Dodd-Frank Wall Street Reform and Consumer Protection Act, VoxEU.org (Nov. 24, 2010), http://www.voxeu.org/ index.php?q=node/5692 [https://perma.cc/NY9B-D5JW] ("In the US, the Dodd-Frank Act passed earlier this year represents the most sweeping set of reforms to the US financial sector since the Great Depression.”).

${ }^{66} 15$ U.S.C. $\$ 1639$ c (2012).

677 U.S.C. $\$ 26(\mathrm{n})(2)(2012)$.

${ }^{68}$ See Creating the Consumer Bureau, supra note 13.

${ }^{69} 12$ U.S.C. $\$ 5518$ (2012); 15 U.S.C. § 780 (2012).

${ }^{70}$ See Department of Defense Appropriations Act, 2010, Pub. L. No. 111-118, § 816(a), 123 Stat. 3409 (2009). 
legal change. ${ }^{71}$ In that Burkean spirit of cautious, incremental law reform, this Article offers centrist proposals that I believe would move adhesive arbitration law from its current position on the right to about where I believe the center is.

To reiterate though, moving law toward the center is not my primary purpose in making these proposals. Rather, these proposals are what I believe would be good policy. Most of these beliefs are long-held, and I have advocated some of them before. ${ }^{72}$ I believe the positions I advocate in this Article rest on the principle that has long animated my normative arbitration scholarship—what I call the "contractual approach"73 to arbitration law, which is that arbitration agreements should generally be as enforceable as other contracts, rather than more or less enforceable. Applying this principle to adhesive arbitration agreements yields a set of proposals that I hope is timely and congenial to the CFPB, Congress, and the Supreme Court-all of whom make law governing adhesive arbitration agreements. ${ }^{74}$

\section{Framework to Understand the Arbitration Debate: Requiring DifFERENT LeVels of Consent to Trade Away the Right to Litigate}

\section{A. Five Positions on a Left-Right Continuum}

As noted above, the ideological divide over adhesive arbitration agreements fits a century-long pattern in which regulation of adhesion contract

${ }^{71}$ See Edmund Burke, Reflections on the Revolution in France, in 19 RETHINKING THE Western Tradition (Frank M. Turner ed., Yale Univ. Press 2003) ("A state without the means of some change is without the means of its conservation. Without such means it might even risk the loss of that part of the constitution which it wished the most religiously to preserve."); Brad Masters, Reconciling Originalism with the Father of Conservatism: How Edmund Burke Answers the Disruption Dilemma in N.L.R.B. v. Noel Canning, 2013 BYU L. REv. 1061, 1073-74 (2013) ("Burke faced a dilemma. Philosophic and institutional evolution is both natural and desirable; yet, change can exact significant, retrogressive costs on society. Burke navigated this problem by advocating for gradual change and respect for precedent." (footnotes omitted)).

${ }^{72}$ See generally Stephen J. Ware, Vacating Legally-Erroneous Arbitration Awards, 6 Y.B. on Arb. \& Mediation 56 (2014); Stephen J. Ware, Arbitration Law's Separability Doctrine After Buckeye Check Cashing, Inc. v. Cardegna, 8 Nev. L.J. 107 (2007); Stephen J. Ware, Interstate Arbitration: Chapter 1 of the Federal Arbitration Act, in EDWARD BRUNET, RICHard E. Speidel, Jean R. Sternlight \& Stephen J. Ware, Arbitration Law in America: A Critical Assessment 88-126 (2006); Stephen J. Ware, The Case for Enforcing Adhesive Arbitration Agreements - with Particular Consideration of Class Actions and Arbitration Fees, 5 J. Ам. Аrв. 251 (2006).

${ }^{73}$ Stephen J. Ware, Employment Arbitration and Voluntary Consent, 25 Hofstra L. Rev. 83, 86 (1996) ("Part III is an argument for a contractual approach to arbitration law-an argument that arbitration law is, and ought to be, essentially a branch of contract law."); Stephen J. Ware, Arbitration and Unconscionability After Doctor's Associates, Inc. v. Casarotto, 31 Wake Forest L. Rev. 1001, 1034 (1996) ("For two decades, the Supreme Court has advanced the contractual approach to arbitration law." (footnote omitted)).

${ }^{74}$ See supra notes $11-15$ and accompanying text. 
terms is advocated by progressives who tend to see it as democratically protecting vulnerable people from rapacious businesses, rather than by conservatives who tend to see such regulation as raising costs to, and restricting the freedom of, both parties to the contract..$^{75}$ Throughout this long-term debate the relevant question, in its simplest form, is whether or not the law should enforce various contract terms. When the contract term in question is an agreement to arbitrate, the two polar positions ("always enforce them" and "never enforce them") are not the only possible positions. Rather, several positions can be arrayed on a continuum largely corresponding to the level of consent the law should require before enforcing an arbitration agreement against a consumer, employee, or other individual. Below is a diagram of the continuum, which summarizes five positions and labels them the Very Progressive Position, the Moderately Progressive Position, the Centrist Position, the Moderately Conservative Position, and the Very Conservative Position:

Left $\begin{array}{lllll}\begin{array}{l}\text { Very } \\ \text { Progressive }\end{array} & \begin{array}{l}\text { Moderately } \\ \text { Progressive }\end{array} & \text { Centrist } & \begin{array}{l}\text { Moderately } \\ \text { Conservative }\end{array} & \begin{array}{l}\text { Very } \\ \text { Conservative }\end{array} \\ \begin{array}{l}\text { post-dispute } \\ \text { consent }\end{array} & \begin{array}{l}\text { non-adhesive } \\ \text { consent }\end{array} & \begin{array}{l}\text { contractual } \\ \text { consent }\end{array} & \begin{array}{l}\text { contractual } \\ \text { consent with } \\ \text { no defenses }\end{array} & \begin{array}{l}\text { contractual } \\ \text { consent with } \\ \text { exculpatory } \\ \text { effects and no } \\ \text { defenses }\end{array}\end{array}$

${ }^{75}$ See, e.g., Jean Braucher, Deception, Economic Loss and Mass-Market Customers: Consumer Protection Statutes as Persuasive Authority in the Common Law of Fraud, 48 ArIz. L. REv. 829, 833 (2006) ("[T]he conservative side in the legal culture war believes customers should insist on warranties to protect themselves against deceptive practices, and if they don't, caveat emptor ... . "); Sidney W. DeLong, Placid, Clear-Seeming Words: Some Realism About the New Formalism (with Particular Reference to Promissory Estoppel), 38 SAN Diego L. REv. 13, 50 (2001) ("[R]ealist/progressive principles such as bad faith and unconscionability crystallized into consumer protection legislation and agency regulation . . .."); Robert Hockett, Whose Ownership? Which Society?, 27 CARDozo L. Rev. 1, 22 (2005) ("Lochner infamously favored libertarian-liberal freedom of contract over egalitarian-liberal equalizing of de facto bargaining power and consequent opportunity." (footnote omitted)); Duncan Kennedy, From the Will Theory to the Principle of Private Autonomy: Lon Fuller's "Consideration and Form", 100 Colum. L. Rev. 94, 173 (2000) ("[C]ontract doctrine was the site . . o of a[ ] . . . mildly ideologized debate between conservatives touting freedom of contract, on one side, and liberals advocating policing bargains in the interests of weak parties, on the other."); Margaret H. Lemos, State Enforcement of Federal Law, 86 N.Y.U. L. Rev. 698, 738 (2011) ("[T]here is some evidence to suggest that the decision by an elected attorney general to take action in the consumer-protection field is influenced by citizen ideology: Attorneys general from 'liberal' states do more, while those from 'conservative' states do less." (footnote omitted)); Matthew Lister, Citizenship, in the Immigration Context, 70 MD. L. REv. 175, 231-32 (2010) ("If there were no limits on what could be bargained for, this would be a serious problem. Such a system would be a libertarian system (rather than liberal) that gives unrestricted freedom of contract a place of pride. Liberal theories rightly reject such unrestricted freedom of contract." (footnotes omitted)); Amy Widman, Advancing Federalism Concerns in Administrative Law Through A Revitalization of State Enforcement Powers: A Case Study of the Consumer Product Safety and Improvement Act of 2008, 29 YALE L. \& PoL'y Rev. 165, 198 (2010) (referring to "the basic progressive tradition of consumer protection"). 
The next several pages explain the continuum and the five positions, after first exploring the key concept: the right to litigate.

\section{B. Trading Away the Right to Litigate}

\section{Settlement Agreements and Exculpatory Clauses}

Litigation is the default process of dispute resolution in the sense that parties can contract into alternative processes of dispute resolution, but if they do not, then each party retains the right to have the dispute resolved in litigation. ${ }^{76}$ The right to litigate is important, especially in the United States. ${ }^{77}$ Access to courts is basic to our system of government. ${ }^{78}$

The right to litigate is alienable. For example, a settlement agreement is an agreement through which the plaintiff (or other claimant) alienates her right to litigate her claim against the defendant. Typically, the defendant pays the plaintiff money or some other consideration in exchange for the plaintiff trading away her right to litigate that claim. In other words, a settlement is essentially a plaintiff contractually negating her claim against a defendant by trading away the right to litigate it.

${ }^{76}$ Ware, Vacating Legally-Erroneous Arbitration Awards, supra note 72, at 59; see also Christopher R. Drahozal, Why Arbitrate? Substantive Versus Procedural Theories of Private Judging, 22 Am. Rev. INT'L ARB. 163, 165 (2011) ("The default form of dispute resolution is litigation. Parties resolve their disputes in court unless they agree otherwise. Arbitration is often described as an alternative means of dispute resolution. Instead of parties relying on a public court judge to issue a final and binding decision, they hire an arbitrator (or arbitrators) to do so. By agreeing to arbitrate, parties override the litigation default rule." (footnotes omitted)).

77 The judiciary and litigation have long played a larger role in the United States than in other democracies. See Robert A. Kagan, Adversarial Legalism: The American Way of LAW 13 (2001) ("[V]iewed in the comparative perspective, the United States is distinctive .... It is especially inclined to authorize and encourage the use of adversarial litigation to . . . resolve disputes."); id. ("Adversarial legalism gives the United States the most politically and socially responsive court system in the world .... [T] he judiciary and lawyers [are] more fully part of the governing process and more fully democratic in character."); Developments in the Law-The Law of Marriage and Family, Inching Down the Aisle: Differing Paths Toward the Legalization of Same-Sex Marriage in the United States and Europe, 116 Harv. L. Rev. 2004, 2012 (2013) ("[T]he judiciary has played a much more significant role in the United States [than in Europe]."); David Nelken, Beyond Compare? Criticizing "The American Way of Law", 28 LAw \& Soc. INQUiRY 799, 819 (2003) ("[I]f we were trying to draw any general lesson from studying the range of law and governance structures in modern democracies .... What we can be certain of is that in these other places lawyers are less central and litigation is allowed a much smaller role than in the United States.").

${ }^{78}$ Judith Resnik, Diffusing Disputes: The Public in the Private of Arbitration, the Private in Courts, and the Erasure of Rights, 124 YALE L.J. 2804, 2818 (2015) ("Constitutional text, doctrine, and common law traditions establish the authority of individuals to bring claims to courts and the obligation of courts to welcome third parties to observe their proceedings. State constitutions regularly linked the two forms of access by mandating rights-to-remedies in open courts."). 
Courts' routine enforcement of settlement agreements emphasizes the alienability of the right to litigate. ${ }^{79}$ However, settlement agreements are formed after a dispute has arisen. In contrast, pre-dispute agreements to negate claims by trading away the right to litigate them are often unenforceable. ${ }^{80} \mathrm{~A}$ pre-dispute agreement to negate claims-especially when that agreement is just one clause of a broader contract-is typically called an "exculpatory clause." Exculpatory clauses are often unenforceable. As David Schwartz writes,

Courts generally hold contract clauses to be void as against public policy if their effect is to exempt a party from liability for its own future fraud or intentional torts, violations of statute, and injuries caused by gross negligence or recklessness. Exculpatory clauses in contracts are enforceable only to the extent that they cover simple negligence, and even then with significant limitations. ${ }^{81}$

For example, a California statute prohibits enforcement of contracts that "exempt anyone from responsibility for his own fraud, or willful injury to

79 " $[$ C]ourts are generally happy to bless the parties' settlement without inquiring about its terms." WARE, supra note 56, at § 2.47 (citing Mars Steel Corp. v. Cont'l Ill. Nat'l Bank \& Tr. Co., 834 F.2d 677, 681 (7th Cir. 1987)) ("The fairness of a settlement of a legal dispute is like the adequacy of the consideration supporting a contractual promise: a matter best left to negotiation between the parties."). See generally 15A C.J.S. Compromise \& SETTLEMENT § 33 (2014) ("As a general rule, a settlement agreement is considered valid and enforceable if it is entered into in good faith, and courts will not invalidate settlement agreements absent a strong showing that they violate good morals or the public interest because of error, bad faith, or fraud." (footnotes omitted)); Baptist v. City of Kankakee, 481 F.3d 485, 492 (7th Cir. 2007) (holding that plaintiffs received value in exchange for the settlement of their claim, and therefore the Court will not inquire to adequacy of settlement terms); Russell v. United States, 320 F.2d 920, 928 (Ct. Cl. 1963) ("Because it is not normally concerned with the soundness of a compromise, the court customarily accepts stipulated settlements calling for judgments against the United States, without any inquiry into the correctness of the legal principles or factual assumptions on which the compromise may be founded."); Trenton St. Ry. Co. v. Lawlor, 71 A. 234, 236 (N.J. 1908) ("The court will not inquire into the adequacy or inadequacy of the consideration of a compromise fairly and deliberately made.").

${ }^{80}$ See infra notes 81-85 and accompanying text.

${ }^{81}$ David S. Schwartz, Enforcing Small Print to Protect Big Business: Employee and Consumer Rights Claims in an Age of Compelled Arbitration, 1997 WIs. L. REv. 33, 112 (1997); see also Margaret Jane Radin, Boilerplate: The Fine Print, Vanishing Rights and the RULE OF LAw 139 (2013) ("Although courts would most likely uniformly invalidate as against public policy exculpatory clauses that immunize intentional harm or reckless or grossly negligent behavior ... some courts now do enforce exculpatory clauses insofar as they apply to merely negligent behavior."). For a lengthier discussion of the same, see Michael A. Scodro, Deterrence and Implied Limits on Arbitral Power, 55 Duke L.J. 547, 589-90 (2005) (footnotes omitted):

Certain rights cannot be traded away, at least prospectively, by the parties who enjoy their protections. Often called "exculpatory" clauses, contract provisions waiving a party's right to sue are therefore frequently unenforceable. Congress and the courts have made plain that parties cannot contract away the right to sue to vindicate any of an array of statutory rights . . . . Many common law actions, including suits for intentional, reckless, and even grossly negligent torts, also cannot be waived prospectively. Often, courts allow actions for even common negligence to proceed notwithstanding a predispute waiver. 
the person or property of another, or violation of law, whether willful or negligent . . . "\$2 Despite this statute, however, California courts often enforce contracts exculpating a party "from liability for ordinary negligence ... where no public interest is involved ... and no statute expressly prohibits it." ${ }^{83}$ For example, courts generally enforce exculpatory clauses in the recreational sports context. ${ }^{84}$ In contrast, the California Supreme Court did not enforce an exculpatory clause in a contract between a hospital and an entering patient because it held that contract affects the public interest. ${ }^{85}$

Why does our law routinely enforce post-dispute agreements to negate claims (settlement agreements) but often not enforce pre-dispute agreements to negate claims (exculpatory clauses)? Two major reasons come to mind. First, the level of consent to settlement agreements tends to be very high. Settlement agreements are formed post-dispute, and often after litigation has begun. At this point, even the least sophisticated parties are likely advised by a lawyer and focused on resolving a particular disputed claim. Thus, they are likely to appreciate the main right they lose by settling: the right to continue litigating the claim. ${ }^{86}$ So while a settling plaintiff may be an unsophisticated or vulnerable consumer or employee negating her claim by trading away an important right (the right to litigate it), such individuals consent to that trade when they tend to have their greatest understanding of and appreciation for that right.

In contrast, an exculpatory clause in a contract with many other clauses is formed pre-dispute when a party who had no role in drafting the contract-such as an unsophisticated or vulnerable consumer or employeemay have little appreciation for the right to litigate and the exculpatory clause's negation of it. That individual may not even notice the exculpatory clause in the contract, let alone understand it and reflect on it, much less discuss it with counsel. Relatedly, the contract containing the exculpatory clause is part of a transaction with a benefit (such as a product or a loan of

${ }^{82}$ Cal. Civ. Code $\S 1668$ (2013); see also Kalisch-Jarcho, Inc. v. City of New York, 448 N.E.2d 413, 416 (N.Y. 1983) (discussing New York state law's avoidance of exculpatory clauses that insulate corporations from backlash for intentional or reckless wrongdoing).

${ }^{83}$ Health Net of Cal., Inc. v. Dep't of Health Servs., 113 Cal. App. 4th 224, 243 (2003) (citing 1 WitKIn, Summary of Cal. Law Contracts $\$ 631$ (9th ed. 1987)).

${ }_{84}$ Platzer v. Mammoth Mountain Ski Area, 104 Cal. App. 4th 1253, 1258-59 (2002).

${ }^{85}$ Tunkl v. Regents of Univ. of Cal., 383 P.2d 441, 442 (Cal. 1963).

${ }^{86}$ Ware, Vacating Legally-Erroneous Arbitration Awards, supra note 72, at 64-65; see Schwartz, supra note 81, at 116-17.

An individual weighing an offer to settle a claim based on acts that have already occurred has concrete wrongs to evaluate and is in a much better position to assess the extent of her harm than an individual thinking about future potentialities. She has more incentive to contact a lawyer. Particularly with legal representation, the person who has already been injured is in a much better position to evaluate her legal claims. A settlement can thus result from a bargain "in the shadow of the law," that is, taking into account the costs of potential litigation for both parties, the range of outcomes before a judge or a jury, and the facts and issues of proof in light of the legal standards. 
money) for the individual, but that benefit is probably not overtly tied to the claim she is negating. So the individual may simply think she is receiving a product or loan in exchange for her promise to pay money, as opposed to having a more thorough understanding that the contract provides that she is receiving the product or loan in exchange for all her promises in all the contract's clauses. In short, she may not realize that price is merely one term of the contract and that other contract terms (such as an exculpatory clause) likely affect the price at which the business is willing to contract. ${ }^{87}$

The second major reason our law routinely enforces (post-dispute) settlement agreements but usually does not enforce exculpatory clauses (predispute settlement agreements) relates to deterrence. As Michael Scodro emphasizes, the deterrence goal of Congress or other lawmakers tends to:

loom[ ] particularly large before a dispute arises. At that point, society's primary interest in a putative right of action lies in its ability to deter misconduct: "Remedies have both deterrent and compensatory effects, but at different times in the process, deterrence or compensation may predominate. Prior to the existence of a particular dispute, the potential availability of compensatory remedies acts purely as a deterrent, telling potential defendants how to order their conduct." 88

In contrast, "[s]ettlement after the fact is, of course, permissible . . . because unlike 'prospective waivers,' [such as exculpatory clauses] settlements do not 'affect the public interest by diminishing deterrence." " ${ }_{89}$

\section{Default Rules and Mandatory Rules}

Professor Scodro writes " $[t]$ he deterrent effect of nonwaivable rights is of the utmost importance, not solely to the individual who may become the

${ }^{87}$ That contract terms favorable to sellers go hand-in-hand with lower prices "has been standard in the law-and-economics literature for at least a quarter of a century." Stephen J. Ware, Paying the Price of Process: Judicial Regulation of Consumer Arbitration Agreements, 2001 J. Disp. Resol. 89, 92 (2001); see also Korobkin, supra note 21, at 1203, 1206.

Terms that govern the contractual relationship between buyers and sellers are attributes of the product in question, just as are the product's price and its physical and functional characteristics. Because buyers are boundedly rational rather than fully rational decisionmakers, when making purchasing decisions they take into account only a limited number of product attributes and ignore others. While sellers have an economic incentive to provide the efficient level of quality for the attributes buyers consider ("salient" attributes), they have an incentive to make attributes buyers do not consider ("non-salient" attributes) favorable to themselves, as doing so will not affect buyers' purchasing decisions. Assuming that price is always a salient product attribute for buyers, market competition actually will force sellers to provide lowquality non-salient attributes in order to save costs that will be passed along to buyers in the form of lower prices.

${ }^{88}$ Scodro, supra note 81, at 591-92 (quoting Schwartz, supra note 81, at 118) (footnote omitted).

${ }^{89} I d$. at 591 (quoting Schwartz, supra note 81, at 118) (footnotes omitted). 
victim of misconduct, but also to third parties and to society generally." 90 Here lies the important distinction between mandatory rules of law and default rules. ${ }^{91}$ A mandatory (or "nonwaivable") rule creates rights that cannot be traded away in a pre-dispute contract, but can be traded away in a postdispute contract (such as a settlement agreement). In contrast, a default rule creates rights that can be traded away in a pre- or post-dispute contract. For example, in a sale of goods under the Uniform Commercial Code, the default rule is that the seller's place of business is the place for delivery of the goods, but the parties can opt out of that default with a pre-dispute contract term requiring delivery at some other location..$^{92}$

Default rules are very common in contract and commercial law. ${ }^{93}$ Mandatory rules are common in many other areas of law, particularly in areas of law_-such as consumer, employment, labor, securities, and franchise law-replete with statutes and regulations prohibiting various arguably oppressive contract terms. ${ }^{94}$ These differing approaches fit a general sense of contract and commercial law as allowing parties to a transaction the contractual freedom to achieve their goals (even if those goals displease non-

${ }^{90} \mathrm{Id}$. at 591.

${ }^{91}$ See, e.g., Ian Ayres \& Robert Gertner, Filling Gaps in Incomplete Contracts: An Economic Theory of Default Rules, 99 YALE L.J. 87, 87 (1989) (distinguishing between "default" rules, which parties can modify by contract, and mandatory or "immutable" rules, which "parties cannot change by contractual agreement" (footnote omitted)).

${ }^{92}$ U.C.C. § 2-308 (AM. LAw INST. \& UNIF. LAw Comm'N 1977) ("Unless otherwise agreed (a) the place for delivery of goods is the seller's place of business or if he has none his residence ....").

${ }^{93}$ See, e.g., Bruce L. Hay et al., Litigating BP's Contribution Claims in Publicly Subsidized Courts: Should Contracting Parties Pay Their Own Way?, 64 Vand. L. Rev. 1919, 1955 (2011) ("In commercial-contract cases, most of the legal questions relate to "default rules' . . . ."); Jennifer S. Martin, An Emerging Worldwide Standard for Protections of Consumers in the Sale of Goods: Did We Miss an Opportunity with Revised UCC Article 2?, 41 TEX. InT'L L.J. 223, 266 (2006) ("Current Article 2 and contract law in general is premised on the notion of freedom of contract and party autonomy." (footnote omitted)); Edith R. Warkentine, Article 2 Revisions: An Opportunity to Protect Consumers and 'Merchant/Consumers' Through Default Provisions, 30 J. Marshall L. Rev. 39, 44 (1996) ("Freedom of contract is a guiding principle of the U.C.C." (footnote omitted)); see also Mich. Nat'l Bank v. Mich. Livestock Exch., 439 N.W.2d 884, 888 (Mich. 1989) (quoting 2 White \& Summers, UnIFORM Commercial Code $\$ 21-2$, at 135 (3d ed.)) (stating that in Article 2, "freedom of contract is the rule rather than the exception"); Hayward v. Postma, 188 N.W.2d 31, 32 (Mich. Ct. App. 1971) ("The general approach of Article 2 of the code is that freedom of contract prevails . . ..”); Milton M. Cooke Co. v. First Bank \& Trust, 290 S.W.3d 297, 304 (Tex. App. 2009) ("[T]he UCC recognizes freedom of contract and specifies that parties may vary "the effect' of UCC provisions by agreement, except as proscribed by the Code.").

${ }^{94}$ See supra notes 23-27; see also David S. Schwartz, Understanding Remedy-Stripping Arbitration Clauses: Validity, Arbitrability, and Preclusion Principles, 38 U.S.F. L. REV. 49, 54 (2003)

Many regulatory statutes-particularly those protecting consumers or investorscontain "anti-waiver" provisions that expressly guarantee against contract terms purporting to waive the statutes' protections. Even without such statutory provisions, prospective waivers of such statutory protections are routinely struck down as unconscionable, void as against public policy, or simply because they would " "nullify the purposes' of the statute." 
parties) while other areas of law are more willing to regulate a contract (and thus hinder at least one of the parties to it), not only to protect the other contracting party but also to protect non-parties through deterrence. For these reasons, exculpatory clauses are much more consistent with contract and commercial law than with these other areas of law.

To put it another way, one can distinguish mandatory from default rules by determining whether the right recognized by a particular rule can be the subject of an enforceable exculpatory clause. If it can, then the right is merely the default, but if the right cannot be the subject of an enforceable exculpatory clause, then the right is protected by a mandatory rule. For example, when a contract for the sale of goods specifies delivery at the buyer's place of business, the contract contains (although few speak of it this way) an exculpatory clause in which the seller exculpates the buyer from liability for the buyer's failure to take delivery of the goods ("accept" the goods) at seller's place. ${ }^{95}$ This is just one of millions of examples of contracting around default rules. Countless enforceable contract terms are in this sense enforceable exculpatory clauses because they contract around the default rule predispute. Exculpatory clauses, in this broad sense, are so common in contract and commercial law that they are not typically called exculpatory clauses. Instead the phrase "exculpatory clause" seems often used with a pejorative connotation that suggests a clause purporting to contract around that which perhaps should not be contracted around pre-dispute.

\section{The Very Progressive Position on Arbitration: Enforce No Pre- Dispute Arbitration Agreements}

Like a settlement agreement and an exculpatory clause, an arbitration agreement also trades away the right to litigate. However, when parties form an arbitration agreement they do not simply negate their claims but rather replace their rights to litigate claims with rights to arbitrate claims. An arbitration agreement can resemble a settlement agreement in being formed post-dispute, when parties are most likely to appreciate the main right they lose by forming the agreement- the right to continue litigating the dispute. ${ }^{96}$

${ }^{95}$ U.C.C. § 2-501(1) (Aм. Law Inst. \& UNIF. Law Comm’N 1977) ("Tender of delivery is a condition to the buyer's duty to accept the goods and, unless otherwise agreed, to his duty to pay for them. Tender entitles the seller to acceptance of the goods and to payment according to the contract.").

${ }^{96}$ See Keith N. Hylton, Agreements to Waive or to Arbitrate Legal Claims: An Economic Analysis, 8 Sup. CT. Econ. Rev. 209, 288 (2000) ("Because of the similarity in economic terms between post-dispute arbitration agreements and settlement agreements, they should be considered on the same terms in policy discussions. Arguments against post-dispute arbitration agreements are economically indistinguishable from arguments against settlement."); see also Douglas E. Abrams, Arbitrability in Recent Federal Civil Rights Legislation: The Need for Amendment, 26 ConN. L. Rev. 521, 561 (1994) ("A post-dispute arbitration agreement is tantamount to an agreement to allow a neutral to play a role in settling the dispute."); C. Edward Fletcher, III, Privatizing Securities Disputes Through the Enforcement of Arbitration Agreements, 71 MinN. L. Rev. 393, 422 (1987) ("Agreements to arbitrate existing disputes are 
However, most arbitration agreements are (like exculpatory clauses) formed pre-dispute when parties' understanding tends to be much lower. ${ }^{97}$

A pre-dispute arbitration agreement nearly always consists of an arbitration clause among many non-arbitration clauses in a contract. For example, a form contract prepared by Seller's lawyer for all of Seller's sales of goods might include among its thirty clauses, stretching over five pages, a clause requiring Seller and Buyer to arbitrate, rather than litigate, any dispute arising out of or relating to the transaction. When Buyer signs the form or otherwise manifests assent to it, Buyer might not read the arbitration clause, let alone understand it and reflect on it, much less discuss it with counsel or negotiate it with Seller. In addition, a pre-dispute arbitration agreement is typically a broad agreement about how to resolve any dispute that may arise between the parties, so it is generally difficult-even for parties thinking about arbitration while forming the contract-to anticipate all the possible disputes that might arise and assess how a duty to arbitrate, rather than litigate, will affect each of them..$^{98}$

For these reasons, some believe that individuals' pre-dispute arbitration agreements should never be enforced. For instance, Jean Braucher asserted that "[c]onsumer 'choice' of arbitration can only be meaningful if it is a post-dispute choice, when the consumer is represented by counsel. . . . The best way to reform arbitration systems is to make pre-dispute arbitration clauses unenforceable in consumer contracts." 99 This position, opposition to enforcing individuals' pre-dispute arbitration agreements, is the Very Pro-

closely akin to settlement agreements."); Ware, Vacating Legally-Erroneous Arbitration Awards, supra note 72, at 65-66 ("A post-dispute arbitration agreement is essentially a settlement agreement that leaves some of its important terms unspecified until the arbitrator specifies them.”).

${ }^{97}$ See Christopher R. Drahozal, Is Arbitration Lawless?, 40 Loy. L.A. L. Rev. 187, 209 (2006) ("[T]he use of post-dispute arbitration agreements is rare relative to the use of predispute arbitration agreements.”); Christopher R. Drahozal \& Samantha Zyontz, Private Regulation of Consumer Arbitration, 79 TENN. L. Rev. 289, 346 (2012) (noting 96.3\% of cases arose out of pre-dispute agreements, while only $3.7 \%$ arose out of post-dispute agreements to arbitrate); Lewis L. Maltby, Out of the Frying Pan, into the Fire: The Feasibility of PostDispute Employment Arbitration Agreements, 30 WM. Mitchell L. Rev. 313, 319 (2003) (analyzing the American Arbitration Association data on the infrequency of post-dispute arbitration clauses in employment cases).

${ }^{98}$ Ware, Vacating Legally-Erroneous Arbitration Awards, supra note 72, at 63-64.

${ }^{99}$ See, e.g., Jean Braucher, Common Sense and Contracts Symposium: The Gateway Thread-AALS Contracts Listserv, 16 Touro L. Rev. 1147, 1167 (2000) ("Consumer 'choice' of arbitration can only be meaningful if it is a post-dispute choice, when the consumer is represented by counsel who can evaluate the system's rules. The best way to reform arbitration systems is to make pre-dispute arbitration clauses unenforceable in consumer contracts, so that the arbitration systems view consumers as customers as much as the businesses they deal with."); Charles Knapp, Common Sense and Contracts Symposium: The Gateway ThreadAALS Contracts Listserv, 16 Touro L. Rev. 1147, 1173 (2000) ("I think Jean Braucher has hit the nail in precisely the right place-if arbitration is so economically sound for everybody, then let the consumer be persuaded 'once the dispute has arisen' that arbitration is in her best 
gressive Position on arbitration agreements. The Very Progressive Position would require the highest level of consent-post-dispute consent-before enforcing individuals' agreements to arbitrate and thus is at the Left end of the continuum on the level of consent the law should require to trade away the right to litigate.

The Very Progressive Position is the thrust of the Arbitration Fairness Act, which would prohibit enforcement of consumers' and employees' predispute arbitration agreements. The Arbitration Fairness Act says "no predispute arbitration agreement shall be valid or enforceable if it requires arbitration of an employment dispute, consumer dispute, antitrust dispute, or civil rights dispute." 100 The Arbitration Fairness Act is not targeted at adhesive arbitration agreements; it attacks non-adhesive pre-dispute arbitration agreements as well. It would generally require that individuals' arbitration agreements be formed post-dispute to be enforceable.

\section{The Moderately Progressive Position on Arbitration: Enforce Non- Adhesive Pre-Dispute Arbitration Agreements}

The Moderately Progressive Position is targeted at adhesive arbitration agreements, in contrast to the Very Progressive Position. While the Very Progressive Position would never enforce individuals' pre-dispute arbitration agreements, the Moderately Progressive Position would enforce an individual's pre-dispute arbitration agreement if it is non-adhesive. ${ }^{101}$

interests too. The argument that 'but then the consumer might have a lawyer' obviously proves too much.").

${ }^{100}$ Arbitration Fairness Act of 2013, S. 878, 113th Cong. (as reported by the S. Comm. on the Judiciary, May 7, 2013).

${ }^{101}$ For an articulation of the Moderately Progressive Position, see, for example, Jeffrey W. Stempel, A Better Approach to Arbitrability, 65 Tul. L. Rev. 1377, 1431, 1434, 1440 (1991) (defining "adhesion" as "take-it-or-leave-it," and opposing enforcement when "[t]he arbitration clause is part of a contract of adhesion and the subject matter of the contract is vital to contemporary human existence ...").

If, for example, all landlords in a neighborhood, city, or town included arbitration clauses as part of their form leases, tenants could, if this defense applied, set aside the arbitration provision absent some indicia of affirmative tenant consent or some degree of bargaining and exchange. For example, if the landlord offered the apartment at $\$ 550$ per month when the tenant signed a lease providing for arbitration and $\$ 600$ per month when the tenant's lease had no arbitration clause, this would indicate choice and bargaining. Such contracts, even if the terms are standardized and nonnegotiable, may not even be contracts of adhesion because of the choice among different forms and rental rates.

Id. at 1440; see also George H. Friedman, What's a Regulator to Do? Mandatory Consumer Arbitration, Dodd-Frank, and the Consumer Financial Protection Bureau, Disp. Resol. MAg., Summer 2014, at 6 ("[E]nsure that consumers knowingly and voluntarily agree to arbitrate ..." by enforcing consumers' pre-dispute arbitration agreements only if they are "optional," that is, "[a] consumer cannot be denied goods or services if the consumer declines the arbitration option ...."). 
Individuals rarely form non-adhesive pre-dispute contracts, ${ }^{102}$ including non-adhesive pre-dispute arbitration agreements. For a hypothetical example of a non-adhesive pre-dispute arbitration agreement, consider a credit card with a sixty-dollar annual fee. Suppose a month after the consumer receives and starts using her card the card issuer offers her a five-dollar-per-year rebate if she signs a document containing only an arbitration agreement (no other terms) and then mails that arbitration agreement to the issuer. A consumer who does that thereby forms a non-adhesive pre-dispute arbitration agreement. It is non-adhesive because agreeing to arbitration was not necessary for the consumer to get or keep using this credit card. The consumer could have left the contract terms as they were (she pays sixty dollars per year and retains her right to litigate) or pay fifty-five dollars per year while replacing her right to litigate with a right to arbitrate. The price/arbitration choice is up to the consumer, and it is the same credit card (with other contract terms the same) whether the consumer chooses arbitration or not. The consumer's path of least resistance is the high-price/no-arbitration option, because if the consumer does nothing but use her card then she pays sixty dollars and has no duty to arbitrate. Or she can make it five dollars a year cheaper if she goes through the snail-mail effort of signing the arbitration agreement, finding a stamp and envelope, and putting it all in the custody of the U.S. Postal Service.

A consumer who forms this hypothetical non-adhesive arbitration agreement seems far more likely than a party who "adheres" to an adhesive arbitration agreement (such as Buyer who signed Seller's five-page form contract above ${ }^{103}$ ) to realize she is agreeing to arbitrate, so we might describe this consumer's consent to arbitration as relatively "knowing" consent, ${ }^{104}$ in contrast to the "blanket" 105 adhesive consent Buyer gives to all the terms

${ }^{102}$ See AT\&T Mobility LLC v. Concepcion, 131 S. Ct. 1740, 1750 (2011) ("[T]he times in which consumer contracts were anything other than adhesive are long past." (footnote omitted)); John E. Murray, Jr., The Judicial Vision of Contract: The Constructed Circle of Assent and Unconscionability, 52 DuQ. L. REv. 263, 265 (2014) ("“V]irtually all consumer contracts are 'contracts of adhesion.'" (footnote omitted)); Zachary M. Rupiper, Note, Enforcement Upon the Unwitting: The Overreaching Ability of Courts to Appoint Substitute Arbitration Forums Under the Federal Arbitration Act, 100 Iowa L. Rev. 411, 424 n.88 (2014) ("It is important to note that most consumer contracts are contracts of adhesion, so negotiation generally does not occur.").

${ }^{103}$ See generally Ware, Vacating Legally-Erroneous Arbitration Awards, supra note 72.

${ }^{104}$ Warkentine, Beyond Unconscionability, supra note 21, at 469-74. "Courts should determine the enforceability of certain unbargained-for terms based on a concept I call 'knowing assent.' Knowing assent means more than signing on the dotted line. Knowing assent requires the following: (1) that the unbargained-for term be conspicuous; (2) that the importance of that term be explained so that the adhering party understands its significance; and (3) that the adhering party objectively manifests its assent to that term separately from its manifestation of assent to undertaking a contractual obligation." Id. at 473 (footnotes omitted).

${ }^{105}$ Over fifty years ago, Karl Llewellyn described buyers' consent to the sellers' form contracts as "specific" assent to the "few dickered terms" and "blanket" assent "to any not unreasonable or indecent term the seller may have on his form, which do not alter or eviscerate the reasonable meaning of the dickered terms." Karl Llewellyn, The Common Law TRAdItion: Deciding Appeals 370 (1960). 
(including arbitration) on Seller's form contract. Also distinguishing this consumer from Buyer, this consumer plainly gets something helpful in exchange for-and overtly tied to-agreeing to arbitrate, a five-dollar lower price.

This hypothetical credit card pre-dispute arbitration agreement with the five-dollar-per-year rebate is extremely unusual because, in contrast to this hypothetical, most consumer arbitration agreements:

(1) are adhesive (presented to the consumer as an inseparable part of a "take it or leave it" form contract), so the consumer must forgo the entire transaction (credit, property, or service) with that business to avoid agreeing to arbitrate;

(2) receive only the consumer's blanket (adhesive) consent given generally to all the terms on a form contract by signing or otherwise manifesting assent to it; and

(3) are not overtly tied to a price reduction or other contract term plainly helpful to the consumer.

These distinctions do not matter under the Very Progressive Position, which would refuse to enforce the hypothetical credit card arbitration agreement simply because it was formed by an individual pre-dispute. ${ }^{106}$ In contrast, the first of these distinctions is important under the Moderately Progressive Position, which would enforce the hypothetical credit card arbitration agreement because it is non-adhesive. And the second and third of these distinctions may be important for some versions of the Moderately Progressive Position, as the following paragraphs explain.

While "non-adhesive consent" seems the most concise way to describe the Moderately Progressive Position's requirement for enforcement of an individual's arbitration agreement, a fuller description would delve into the many facts that might lead reasonable people to find an individual's predispute consent to arbitration more meaningful than the blanket consent adhering individuals usually give in one fell swoop to all the terms of adhesion contracts. ${ }^{107}$ For example, some versions of the Moderately Progressive Position would enforce the hypothetical credit card agreement only because postcontracting effort by the consumer was required for her to be bound to a predispute arbitration agreement. (The hypothetical consumer already had the credit card and a contract with her card issuer when she chose to amend that

${ }^{106}$ See supra Part III.C.

${ }^{107}$ See, e.g., Michael Z. Green, Preempting Justice Through Binding Arbitration of Future Disputes: Mere Adhesion Contracts or A Trap for the Unwary Consumer?, 5 LoY. CONSUMER L. Rev. 112, 119 (1993) ("[C]onsumer arbitration is a strong and effective dispute resolution tool if . . . equal bargaining over terms is present."); Jeffrey W. Stempel, Bootstrapping and Slouching Toward Gomorrah: Arbitral Infatuation and the Decline of Consent, 62 Brook. L. REv. 1381, 1406-07 (1996) ("[T] he legal system should focus on whether the consumer was adequately informed and agreed to arbitrate .... If so, such agreements should ordinarily be enforced."). 
contract by mailing the arbitration agreement to the issuer.) In contrast, other versions of the Moderately Progressive Position might enforce a variation of the hypothetical in which the consumer's original contract with the card issuer included an arbitration clause and required the consumer to take some post-contracting effort to opt out of that arbitration clause. For example, under current law some arbitration clauses that might otherwise be held unconscionable avoid that holding by giving the consumer a period of time after contract formation to opt out of the arbitration clause. ${ }^{108}$

Going further, other versions of the Moderately Progressively Position might enforce even adhesive arbitration agreements if the individual adherent consents to the arbitration clause specifically, perhaps by signing or initialing the clause, and provides blanket consent to the contract (to all the contract's clauses), indicated by her signing the broader contract containing the arbitration clause. ${ }^{109}$

On another front, some versions of the Moderately Progressive Position would enforce the hypothetical arbitration agreement even if it lacked the five-dollar-per-year price-reduction, while other versions of the Moderately Progressive Position would make a price reduction, or other plainly-helpful consideration overtly tied to the individual's agreement to arbitrate, a requirement for enforcing that agreement, ${ }^{110}$ and some versions of the Moder-

${ }^{108}$ See, e.g., Circuit City Stores, Inc. v. Ahmed, 283 F.3d 1198, 1199 (9th Cir. 2002); Owings v. T-Mobile USA, Inc., 978 F. Supp. 2d 1215, 1224 (M.D. Fla. 2013) ("[T]hat the consumer may opt-out of arbitration within thirty days of signing the agreement obviates any argument of procedural unconscionability."); Freedman v. Comcast Corp., 988 A.2d 68, 86 (Md. Ct. Spec. App. 2010) (holding that arbitration provision was not procedurally unconscionable as a contract of adhesion because of a clear and conspicuous opt-out provision); see also Guadagno v. E*Trade Bank, 592 F. Supp. 2d 1263, 1270 (C.D. Cal. 2008) ("Guadagno had a meaningful opportunity to opt out of the Arbitration clause, which contained the class action waiver, by notifying $\mathrm{E}^{*}$ Trade in writing within 60 days of receiving the Agreement. The Agreement highlighted the Arbitration clause, and the introduction to the Arbitration clause highlighted the opt out term. Because the Arbitration clause containing the waiver was not presented on a take-it-or-leave-it basis, but gave Guadagno sixty days to opt out, it was not unconscionable.").

${ }^{109}$ See, e.g., Bell v. Cong. Mortgage Co., 30 Cal. Rptr. 2d 205, 210 (Ct. App. 1994) ("Further, we conclude that the enforceability of a compelled arbitration provision in a contract of adhesion requires that the provision appear in clear and unmistakable form by highlighting, bold type, or with an opportunity for specific acknowledgment by initialing."), depublished by Bell v. Cong. Mortgage Co., 1994 LEXIS 4258 (Cal. July 28, 1994); Korobkin, supra note 21 , at 1246 ("[C]ourts could require sellers to procure specific assent to each boilerplate clause in a form contract, perhaps by having buyers initialize each paragraph."); Anthony M. Balloon, Comment, From Wax Seals to Hypertext: Electronic Signatures, Contract Formation, and A New Model for Consumer Protection in Internet Transactions, 50 EMORY L.J. 905, 933 (2001) ("Requiring consumers to type their initials serves several functions. First, initialing makes contracting more intentional. Initialing makes consumers stop and think about what they are agreeing to, instead of the typical scenario in which a consumer haphazardly clicks buttons and links to complete the contracting process in the quickest manner possible.").

${ }^{110}$ See, e.g., Ramona L. Lampley, Is Arbitration Under Attack?: Exploring the Recent Judicial Skepticism of the Class Arbitration Waiver and Innovative Solutions to the Unsettled Legal Landscape, 18 CoRnell J.L. \& PuB. Pol'y 477, 511 (2009) ("[T]here is an even better vehicle for ensuring contemplated consumer choice in accepting the arbitration clause: differ- 
ately Progressive Position might even enforce the arbitration agreement if it was tied to a five-dollar price reduction but not if it was tied to a five-cent price reduction.

In sum, the Moderately Progressive Position is actually a group of positions that require more than blanket consent to an adhesion contract ("adhesive consent") to trade away the right to litigate, but do not require postdispute consent. These Moderately Progressive Positions are therefore to the right of the Very Progressive Position, which requires post-dispute consent, and to the left of the Centrist Position, which generally requires only adhesive (blanket) consent to form an enforceable arbitration agreement and thus trade away the right to litigate.

\section{E. The Centrist Position on Arbitration: Treat Adhesive Arbitration Agreements Like Other Adhesion Contracts}

As just discussed, the Centrist Position on arbitration (unlike both Progressive Positions) would generally enforce individuals' adhesive arbitration agreements. This is because the Centrist Position uses contract law's standards of consent and, by those standards, most terms of most adhesion contracts are the products of mutual consent. Consent in contract law is generally objective rather than subjective. ${ }^{111}$ Specifically, contract law does

entiated pricing by acceptance or rejection at the point of sale. If pre-dispute agreements to individual arbitration accomplish in practice what they should in theory-reduced litigation costs to the business - these savings should be passed along to the consumer in the form of lower prices for consumer products. In other words, the consumer who opts out of binding arbitration in order to preserve a judicial forum and the class mechanism should have to pay a premium in order to preserve potentially expensive litigation to the supplier. Despite the attractions of the differentiated pricing scheme, it has not yet been widely adopted, perhaps due to administrative costs."); Jeremy Senderowicz, Consumer Arbitration and Freedom of Contract: A Proposal to Facilitate Consumers' Informed Consent to Arbitration Clauses in Form Contracts, 32 Colum. J.L. \& Soc. Probs. 275, 302 (1999) (proposing to amend FAA so enforcement of arbitration agreements only applies to "a contract prepared by a merchant and offered to a non-merchant if (1) additional consideration is provided by the merchant for the provision of the contract concerning arbitration; and (2) the merchant provides information to the nonmerchant describing the procedural differences between, and all other factors which may distinguish the outcomes of, the arbitration process and litigation").

${ }^{111}$ See, e.g., Peter A. Alces, Unintelligent Design in Contract, 2008 U. ILl. L. Rev. 505, 527 (2008) ("Contract is animated by objective consent, then, because we cannot reliably determine subjective consent and we need to be able to determine consent."); Wayne Barnes, The Objective Theory of Contracts, 76 U. CIN. L. REv. 1119, 1133 (2006) ("[U]nder the nowdominant objective theory of contracts, subjective intention is irrelevant, and the lack thereof should not prohibit the formation of a contract."); Wayne R. Barnes, Toward a Fairer Model of Consumer Assent to Standard Form Contracts: In Defense of Restatement Subsection 211(3), 82 WASH. L. REv. 227, 252 (2007) ("The objective theory of contracts is the dominant theory of mutual assent in modern contract law."); Korobkin, supra note 21, at 1205 ("[G]iven the complexity of modern commerce . . . [a]ctual [subjective] assent to each contract term in a transaction of any complexity simply is not possible."); Lauren E. Miller, Breaking the Language Barrier: The Failure of the Objective Theory to Promote Fairness in Language-Barrier Contracting, 43 IND. L. REv. 175, 177 (2008) ("Since the late nineteenth century, courts have applied the objective theory to determine which manifestations amount to assent to form a contract."); W. David Slawson, Standard Form Contracts and Democratic Control of Law- 
not require knowing consent to each term on an adhesion contract, but rather routinely enforces contract terms the adhering party probably did not know about when forming the contract, unless she read the entire contract before manifesting her consent to it by signing it, performing it, or some other manifestation such as clicking "agree" on a website containing the contract terms. Such manifestations of assent, ${ }^{112}$ plus consideration, are well established as contract law's requirements to form a contract. ${ }^{113}$ In short, contract law's objective consent standards enforce most adhesive contract terms, ${ }^{114}$ and thus would enforce most adhesive arbitration agreements.

Contract law's objective consent standards enforce most, rather than all, adhesive contract terms. As the Restatement (Second) of Contracts says:

\begin{abstract}
A party who makes regular use of a standardized form of agreement does not ordinarily expect his customers to understand or even to read the standard terms . . . . Customers do not in fact ordinarily understand or even read the standard terms. They trust to the good faith of the party using the form and to the tacit representation that like terms are being accepted regularly by others similarly situated. But they understand that they are assenting to the terms not read or not understood, subject to such limitations as the law may impose. ${ }^{115}$
\end{abstract}

making Power, 84 HARv. L. Rev. 529, 542-43 (1971) ("Of course, a consensual theory of contract does not require actual subjective consent to make a contract binding. It is enough that both parties act, verbally or nonverbally, so as to give each other the reasonable expectation that they understand the meaning which is manifested by either of them. That a person may inadvertently manifest what he does not intend is a possibility which may produce unwanted contracts but which does not reduce the consensual character of contract law. All consensual processes are grounded on manifested rather than unmanifested thoughts, as, indeed, they must be.").

${ }^{112}$ See, e.g., Francis J. Mootz III, After the Battle of the Forms: Commercial Contracting in the Electronic Age, 4 J.L. \& POL'Y FOR INFO. SoC'y 271, 284 (2008) ("[C]ourts have readily concluded that clicking an 'I agree' icon next to an electronic presentation of the seller's terms forms a contract and manifests the purchaser's assent to those terms."); Juliet M. Moringiello, Signals, Assent, and Internet Contracting, 57 Rutgers L. Rev. 1307, 1323 (2005) ("Many courts analyzing click-wrap agreements have found the act of clicking an 'I agree' button to be an explicit manifestation of assent to contract terms."); Warkentine, Beyond Unconscionability, supra note 21, at 471 ("Courts almost always find the requisite outward manifestation of assent based on the act of signing a standard form contract."); Alan M. White \& Cathy L. Manfield, Literacy and Contract, 13 Stan. L. \& Pol'y Rev. 233, 250-51 (2002) ("[J]udiciary's response to adhesion contracts . . . still is to assume manifestation of assent and to apply the 'you signed it, you're bound' rule.").

${ }^{113}$ Restatement (Second) of Contracts $§ 17$ (Am. Law Inst. 1981).

${ }^{114}$ See Korobkin, supra note 21, at 1203, 1204 ("Contract law generally provides for the enforcement of the terms in form contracts, thus essentially allowing the drafting party (almost always the seller in consumer contracts but sometimes the buyer in commercial contracts) to create its own private law to govern its transactions. If the non-drafting party indicates his general assent to the form, courts will enforce the terms contained therein whether or not that party approves of the terms provided, understands those terms, has read them, or even has the vaguest idea what the terms might be about. Limited exceptions are made to this rule, most notably if the terms are found to be 'unconscionable." ").

${ }^{115}$ Restatement (Second) of Contracts $§ 211 \mathrm{cmt}$. b (Am. Law Inst. 1981). 
What are these limitations? An important limitation is found in the Restatement section corresponding to the comment just quoted. Section 211(3) states that the customer does not assent to a form contract term if the seller (the party regularly using the form) "has reason to believe that the [customer] would not have accepted the agreement if he had known that the agreement contained the particular term." 116 This reasoning protects consumers and others from much of the risk posed by form contracts. The consumer does not need to worry that the form contains a term that is "bizarre or oppressive," "eviscerates the non-standard terms explicitly agreed to," or "eliminates the dominant purpose of the transaction," because such terms are not part of the contract. ${ }^{117}$

A related contract law doctrine is unconscionability. Unconscionability is often thought of as coming in two forms: substantive and procedural. ${ }^{118}$ Substantive unconscionability refers simply to contract terms that are "unreasonably favorable" to one side. ${ }^{19}$ Procedural unconscionability deals with the process of contract formation, encompassing "not only the employment of sharp practices and the use of fine print and convoluted language, but a lack of understanding and an inequality of bargaining power." 120

Most statements of the law of unconscionability now hold that both procedural and substantive unconscionability are required before courts will grant relief from a challenged term. Judicial decisions have not consistently followed this principle, however, and some courts have suggested a vaguely mathematical metaphor in which a large amount of one type of unconscionability can make up for only a small amount of the other. ${ }^{121}$

${ }^{116} I d$. $\S 211 \mathrm{cmt}$. f.

${ }^{117}$ Id.; see also Randy E. Barnett, Consenting to Form Contracts, 71 Fordham L. Rev. 627,639 (2002) (“'P] arties who sign forms or click 'I agree' are manifesting their consent to be bound by the unread terms in the forms. They would rather run the risk of agreeing to unread terms than either (a) decline to agree or (b) read the terms. Refusing to enforce all of these terms would violate their freedom to contract. But parties who click 'I agree' are not realistically manifesting their assent to radically unexpected terms. Enforcing such an unread term would violate the parties' freedom from contract.").

${ }^{118}$ Murray, Jr., Judicial Vision of Contract, supra note 102, at 265 ("[T] ion inevitably describes unconscionability as 'procedural' or 'substantive.'”).

${ }^{119}$ See, e.g., E. Allan Farnsworth, Contracts $\$ 4.28$ (2d ed. 1990); Murray, Jr., Judicial Vision of Contract, supra note 102, at 266 ("Substantive unconscionability is concerned with whether a contract, or a term of a contract, is overly harsh, one-sided, or manifests an outrageous degree of unfairness.").

${ }^{120}$ FARnsworth, supra note 119 , at $\S 4.28$; see also Restatement (SECOND) OF ConTRACTS $§ 208$ (Ам. Law Inst. 1981); Murray, Jr., Judicial Vision of Contract, supra note 102, at 265 ("Procedural' unconscionability is concerned with the circumstances under which the contract was negotiated and formed including the conspicuous or inconspicuous form in which the allegedly unconscionable term is found and, in particular, whether a genuine negotiation occurred, versus a take-it-or-leave-it demand that precluded any choice by the party with inferior bargaining power. Where only one party dictates the terms, the agreement is a "contract of adhesion' which is 'procedurally' unconscionable.").

${ }^{121}$ Richard Craswell, Property Rules and Liability Rules in Unconscionability and Related Doctrines, 60 U. CHI. L. Rev. 1, 17 (1993); see also Melissa T. Lonegrass, Finding Room for 
That a contract is adhesive greatly increases the likelihood a court will find it procedurally unconscionable, and some courts go as far as "equat[ing] the finding of a contract of adhesion with the finding of procedural unconscionability." ${ }^{122}$ So contract law's unconscionability doctrine-and its related doctrine summarized in Restatement Section 211(3) - keep contract law's standards of consent from enforcing all adhesive contract terms. By incorporating these consent standards, the Centrist Position on arbitration would enforce most, but not nearly all, adhesive arbitration agreements.

In sum, the Centrist Position on arbitration adopts contract law's standards of consent and thus requires a lower level of consent to trade away the right to litigate than do the two Progressive Positions. In contrast to the two Progressive Positions-which would never enforce individuals' pre-dispute arbitration agreements (the Very Progressive Position) or would only enforce them when non-adhesive (the Moderately Progressive Position) - the Centrist Position would use contract law's standards of consent and thus enforce most adhesive arbitration agreements. ${ }^{123}$ In other words, the Centrist Position on arbitration does not require post-dispute consent or non-adhesive, predispute consent to trade away the right to litigate. For the Centrist Position, pre-dispute consent is usually (but not nearly always) sufficient, even if it is merely the adhesive (blanket) consent consumers generally give to all the terms on a form contract by signing or otherwise manifesting assent to it.

\section{F. The Moderately Conservative Position on Arbitration: The Separability Doctrine}

The Centrist Position requires a higher standard of consent than the Moderately Conservative position. This is because the Centrist Position borrows from contract law both its standards of consent and its defenses to enforcement. In contrast, the Moderately Conservative Position borrows contract law's standards of consent, but rejects contract law's defenses. To put it more precisely, the Centrist Position applies to the right to litigate both contract law's (relatively low) standards of consent and contract law's main tools to police the sometimes harsh results of those low standards of consent-defenses such as misrepresentation, duress, unconscionability, and illegality (or "public policy"). In contrast, the Moderately Conservative

Fairness in Formalism-The Sliding Scale Approach to Unconscionability, 44 LoY. U. CHI. L.J. 1, 11-13 (2012) (discussing conventional requirement to make a strong showing of both forms of unconscionability, and sliding scale's similar requirement that both forms be present, however a lesser showing of one form may be acceptable with a large amount of the other form present); John E. Murray, Jr., Revised Article 2: Eliminating the "Battle" and Unconscionability, 52 S. TEx. L. REv. 593, 606-08 (2011) (discussing requirement of most courts that both substantive and procedural unconscionability be present, and a "sliding scale" approach that allows a large amount of one form of unconscionability to make up for a lack of the other).

${ }^{122}$ See Warkentine, Beyond Unconscionability, supra note 21.

${ }^{123}$ See Stephen J. Ware, Arbitration Clauses, Jury-Waiver Clauses, and Other Contractual Waivers of Constitutional Rights, 67 LAw \& ContemP. Probs. 167, 169 (2004). 
Position removes from the right to litigate the protection of those defenses, leaving just contract law's relatively low consent standards.

For instance, consider this Article's earlier hypothetical. ${ }^{124}$ If Buyer signs Seller's five-page adhesion contract containing thirty clauses, one of which is an arbitration clause, the Centrist Position likely treats that as sufficient consent to trade away the right to litigate ${ }^{125}$ unless Buyer asserts a defense to the enforcement of the contract. ${ }^{126}$ If Buyer does assert such a defense, then the Centrist Position would not treat Buyer as having traded away her right to litigate until a court hears the defense and concludes that its elements are not present. ${ }^{127}$ In other words, the Centrist Position would keep the courthouse door open to parties asserting defenses to enforcement of their contracts containing arbitration clauses. ${ }^{128}$

In contrast, the Moderately Conservative Position on arbitration would close that door. Under the Moderately Conservative Position, if Buyer asserts a defense to enforcement of the five-page adhesion contract, its arbitration clause nevertheless trades away the right to litigate. As examples, under the Moderately Conservative Position if Buyer asserts that her consent to the five-page adhesion contract was induced by misrepresentation or duress a court would not hear that defense, but rather send the dispute to arbitration where Buyer could argue the defense to the arbitrator. ${ }^{129}$ And if Buyer asserts that the five-page adhesion contract requires her to pay an unconscionably high interest rate or a usurious (illegal) interest rate, then under the Moderately Conservative Position a court would not hear that defense, but rather send the dispute to arbitration where Buyer could argue the defense to the arbitrator. ${ }^{130}$

${ }^{124}$ See supra Section III.C.

${ }^{125}$ I say "likely" because of contract doctrines like procedural unconscionability and ReStatement (Second) of Contracts § 211(3) (Am. Law Inst. 1981). See supra notes 116-122 and accompanying text.

${ }^{126}$ Such an assertion is most likely to occur in opposition to a motion to compel arbitration. See 9 U.S.C. $\$ 3$ (2012).

${ }^{127}$ In other words, only an enforceable contract is enough to alienate the right to litigate under the Centrist Position; an allegedly unenforceable contract is not enough.

${ }^{128}$ Only after a court hears and rejects those asserted defenses does the court relegate the unwilling party to arbitration.

${ }^{129}$ See Prima Paint Corp. v. Flood \& Conklin Mfg. Co., 388 U.S. 395, 404 (1967) (holding that the Federal Arbitration Act "does not permit the federal court to consider claims of fraud in the inducement of the contract generally"); SBRMCOA, LLC v. Bayside Resort, Inc., 707 F.3d 267, 274 (3d Cir. 2013) ("[T] he Condominium Association's coercion claim is arbitrable because it is a challenge to the validity (rather than the formation) of the [contract containing the arbitration clause].”); In re FirstMerit Bank, N.A., 52 S.W.3d 749, 756 (Tex. 2001) ("The defenses of unconscionability, duress, fraudulent inducement, and revocation ... must specifically relate to the Arbitration Addendum itself, not the contract as a whole, if they are to defeat arbitration. Defenses that pertain to the entire installment contract can be arbitrated.”); Serv. Corp. Int'l v. Lopez, 162 S.W.3d 801, 810 (Tex. App. 2005) (“[D]uress . . issue relates to the contract as a whole and not solely the arbitration provision. It is therefore an issue to be decided in arbitration.").

${ }^{130}$ See Buckeye Check Cashing, Inc. v. Cardegna, 546 U.S. 440, 445 (2006). 
Despite the possibility Buyer could prove any of these defenses, the Moderately Conservative Position nevertheless holds that the arbitration clause of the contract alienates Buyer's right to litigate. The Moderately Conservative Position reaches this conclusion by treating the arbitration clause as a separately-enforceable agreement from the contract containing it, so if Buyer's defense is not focused on the arbitration clause in particular, then the court enforces that clause as an agreement to arbitrate disputes about whether there is a defense to enforcement of the broader contract containing that clause. ${ }^{131}$ Treating the arbitration clause as a separately enforceable agreement is usually called the "separability doctrine," 132 and having it removes from the right to litigate the protection of the contract defenses. The Moderately Conservative Position supports the separability doctrine and thus would require a lower level of consent to trade away the right to litigate than would the Centrist Position and the two Progressive Positions.

\section{G. The Very Conservative Position: Converting Some Arbitration Agreements into Exculpatory Clauses}

Under the Moderately Conservative Position if an agreement to arbitrate is enforced then that agreement's terms are generally subject to the same limits as other contracts about what rights (other than the right to litigate) can be traded away pre-dispute. ${ }^{133}$ In contrast, the Very Conservative Position would exempt arbitration agreements from some of those limits. In particular, the Very Conservative Position exempts arbitration agreements from limits relating to (1) appealing legally-erroneous decisions, and (2) class actions. By removing these limits, the Very Conservative Position effectively converts some adhesive arbitration agreements into exculpatory clauses and enforces them in circumstances in which comparable non-arbi-

${ }^{131}$ In Buckeye, the Supreme Court held "that, regardless of whether the challenge is brought in federal or state court, a challenge to the validity of the contract as a whole, and not specifically to the arbitration clause, must go to the arbitrator." Id. at 449. Decades earlier, the Court stated that if Prima Paint had argued that there was fraud "directed to the arbitration clause itself," Prima Paint Corp., 388 U.S. at 402, then Prima Paint would have been entitled to a trial on that issue, but was in fact not entitled to a trial because it made a "claim[ ] of fraud in the inducement of the contract generally," id. at 404.

${ }^{132}$ Buckeye uses the term "severability," Buckeye, 546 U.S. at 445, rather than "separability." Interestingly, courts seem to have a slight preference for the former term, while scholars seem to have a stronger preference for the latter. On August 16, 2015, searches in Westlaw revealed 82 cases and 223 secondary sources with the search "arbitration \& "severability doctrine" " and 80 cases and 362 secondary sources with the search "arbitration \& "separability doctrine.',

${ }^{133}$ Exceptions to this generalization may relate to the three topics noted in AT\&T Mobility LLC v. Concepcion: agreements relating to discovery, evidence and jury. 563 U.S. 333, 343 (2011). Under current law, arbitration agreements may be less limited than non-arbitration agreements with respect to these three topics. For example, a pre-dispute contract term reducing discovery, reducing evidentiary rules, or eliminating the possibility of jury trial may be enforced under lower standards of consent if found in an arbitration agreement than in a nonarbitration agreement. 
tration agreements would be unenforceable. In this respect, the Very Conservative Position thus would require a lower level of consent than would the Moderately Conservative Position.

\section{Legally-Erroneous Decisions}

Consider a hypothetical pre-dispute contract that does not have an arbitration clause. Instead, the contract provides that litigation of any disputes shall end with the trial court's judgment. In other words, the contract includes an agreement not to appeal. Because the primary purpose of appeal is to correct legal errors by the trial court, ${ }^{134} \mathrm{a}$ contract clause prohibiting appeal essentially consents to the enforcement of legally erroneous decisions by the trial court. While such a clause might not indicate the parties' consent to a trial court intentionally or negligently reaching a legally erroneous decision, trial courts sometimes make errors of law; when that occurs a contract clause prohibiting appeal would be the parties' consent to enforcement of that legally erroneous decision. Such a contract clause would be extremely unusual and probably unenforceable. ${ }^{135}$ In other words, a general limit on contract terms is that they cannot contract away the right to correct legally erroneous decisions of the trial court, the initial adjudicator. ${ }^{136}$

However, the Very Conservative Position would remove this limit from arbitration agreements by enforcing arbitration agreements that contract away the right to correct legally-erroneous decisions of the initial adjudicator, the arbitrator. The Very Conservative Position would do this by having courts confirm and enforce arbitration awards without reviewing those awards to determine whether the arbitrator correctly applied substantive law. If the arbitrator made an error of law and that error resulted in denying a claim that would have prevailed under a correct decision of law, then a court confirming and enforcing the award allows the arbitration agreement to have

${ }^{134}$ Robin J. Effron, Reason Giving and Rule Making in Procedural Law, 65 AlA. L. Rev. 683, 707 (2013) ("Error correction is the other traditional function of appeals courts. Generally, in American courts, the error-correction function is limited to issues of law, and trial court decisions of fact are rarely reviewed." (citing McAllister v. United States, 348 U.S. 19, 20 (1954))); Irene M. Ten Cate, International Arbitration and the Ends of Appellate Review, 44 N.Y.U. J. INT'L L. \& PoL. 1109, 1141 (2012) ("The near-exclusive focus on legal issues at the appellate level suggests that the legal system of the United States primarily values appellate review for its role in lawmaking . ... . [The system] devote[s] fewer appellate resources to this review for factual errors." (citing Karl N. Llewellyn, The Bramble Bush: On Our Law AND ITs STUdy 36 (1930))).

${ }^{135}$ See Colter L. Paulson, Evaluating Contracts for Customized Litigation by the Norms Underlying Civil Procedure, 45 ArIz. ST. L.J. 471, 492-93 (2013).

136 See id. Colter Paulson searched for cases involving such provisions and concluded that "[o]utside of the arbitration context, there are very few cases dealing with pre-dispute waivers of the right to appeal." Id. In fact, Paulson found only two cases since 1928, one of which he concluded "was simply a weak attempt to call a payment provision an appellate waiver and was rejected as such." Id. The other case involved an agreement that was not truly pre-dispute (a property settlement agreement, in anticipation of divorce, between spouses who had already separated), let alone pre-dispute and adhesive. $I d$. Therefore, it seems no reported case since 1928 involves a truly pre-dispute contract provision prohibiting appeal. 
the same effect as an exculpatory clause: a claim that would have won but for a pre-dispute contract clause loses because that clause is enforced.

In short, arbitration clauses can operate like exculpatory clauses, unless courts police arbitrators' legally-erroneous awards like appellate courts police trial courts' legally-erroneous decisions: with de novo review on questions of law. While appellate courts give de novo review to trial courts' rulings on questions of law, ${ }^{137}$ the Very Conservative Position supports highly deferential judicial review of arbitrators' rulings on questions of law. ${ }^{138}$ In sum, the Very Conservative Position exempts arbitration agreements from otherwise-applicable law prohibiting pre-dispute agreements to comply with, rather than appeal, legally erroneous decisions.

\section{Class Action "Waivers"}

The Very Conservative Position would also exempt arbitration agreements from otherwise-applicable law relating to class actions. Whether a contract includes an arbitration clause or not, the contract may have language by which the parties purport to "waive" (actually trade away ${ }^{139}$ ) their

${ }^{137}$ Robert Anderson IV, Law, Fact, and Discretion in the Federal Courts: An Empirical Study, 2012 Utah L. Rev. 1, 7-8 (2012) ("The decisions in the first category-questions of law-are reviewed 'de novo' by the appellate court, meaning that the appellate court is not required or expected to give any deference to the trial court. . . . In contrast to legal conclusions, factual determinations by the trial court are reviewed deferentially. Appellate review of factual findings by the district court is limited to whether those findings are 'clearly erroneous,' a very high bar to reverse a trial judge's factual findings."); David Frisch, Contractual Choice of Law and the Prudential Foundations of Appellate Review, 56 VAND. L. REv. 57, 77 (2003) ("Traditionally, questions of law are reviewed de novo and questions of fact are reviewable only on a clearly erroneous basis."); Paul R. Gugliuzza, The Federal Circuit As A Federal Court, 54 WM. \& Mary L. Rev. 1791, 1831 (2013) ("Appellate courts review questions of law de novo. . . . In contrast, appellate courts defer to trial court fact-finding." (citing J. ERIC Smithburn, Appellate Review of Trial Court Decisions 8 (2009))); Leandra Lederman, (Un)appealing Deference to the Tax Court, 63 Duke L.J. 1833, 1886 (2014) ("Federal Rule of Civil Procedure 52(a)(6) governs the standard of review of findings of fact in district court bench trials; Rule 52(a)(6) states that 'findings of fact, whether based on oral or other evidence, must not be set aside unless clearly erroneous, and the reviewing court must give due regard to the trial court's opportunity to judge the witnesses' credibility.' The standard of review on legal issues appealed from the district courts is de novo.").

${ }^{138}$ See Hall Street Assocs., L.L.C. v. Mattel, Inc., 552 U.S. 576, 581 (2008) (“[T]he grounds for vacatur and modification provided by $\S \S 10$ and 11 of the FAA are exclusive."); $i d$. at 588 (viewing the FAA's provisions on confirmation and vacatur of arbitration awards "as substantiating a national policy favoring arbitration with just the limited review needed to maintain arbitration's essential virtue of resolving disputes straightaway. Any other reading opens the door to the full-bore legal and evidentiary appeals that can render informal arbitration merely a prelude to a more cumbersome and time-consuming judicial review process and bring arbitration theory to grief in post-arbitration process"). In contrast, the Moderately Conservative, Centrist, and Progressive Positions support less deferential judicial review of arbitrators' rulings on at least some questions of law and thus would be more likely to vacate legallyerroneous arbitration awards. See infra note 146.

${ }^{139}$ See Ware, Contractual Waivers, supra note 123, at 205.

One can alienate one's rights in two ways: in exchange for consideration or in the absence of consideration. To put it another way, one can trade away one's rights, or one can give away one's rights. In some legal contexts, such as contract law, the term 
rights to be part of a class action. Such a contract may say something like the parties "waive their rights to serve as a representative, as a private attorney general, or in any other representative capacity, and/or to participate as a member of a class of claimants." 140 If this sort of language is in a contract with an arbitration clause, then it is often called an "arbitral class waiver." If this sort of language is in a contract without an arbitration clause, then it may be a called a "non-arbitral class waiver."

The Very Conservative Position holds that adhesive arbitral class waivers should be enforced under circumstances in which non-arbitral class waivers would be unenforceable. ${ }^{141}$ In contrast, the Moderately Conservative Position and Centrist Position would enforce adhesive arbitral class waivers only in circumstances in which non-arbitral adhesive class waivers would be enforced; and the Progressive Positions would never enforce adhesive arbitral class waivers because they would not enforce adhesive arbitration agreements at all. In short, the Very Conservative Position would remove from arbitration agreements the limits on class waivers that apply to non-arbitration agreements. The Very Conservative Position would remove otherwiseapplicable law prohibiting class waivers under a fairly wide range of circumstances.

In sum, the Very Conservative Position is at the Right end of the continuum of five positions on arbitration because only the Very Conservative Position would (1) enforce pre-dispute adhesive arbitration agreements, (2) contained in contracts that might be unenforceable due to a contract defense, (3) while removing from those arbitration agreements otherwise-applicable limits relating to appealing legally erroneous decisions and to class waivers.

\section{Current Law's Place on the Continuum ANd PROposals FOR Reform}

Current law adopts the Very Conservative Position. Under current law:

\footnotetext{
"waiver" is often used to refer only to giving away one's rights. Standard accounts of contract law, for example, carefully distinguish the "waiver" of contractual rights, which does not require consideration, from the "modification" of contractual rights, which does.
}

$I d$. (citing FARNSWORTH, supra note 119 , at $\S 8.5$ ). For this reason, "class waiver" is a misleading term to the extent "waiver" implies alienating a right for nothing in return; if the alienating occurs through a contract term then it is better understood as a trade than a waiver.

${ }^{140}$ Jenkins v. First Am. Cash Advance of Ga., LLC, 400 F.3d 868, 872 (11th Cir. 2005) ("YOU ARE WAIVING YOUR RIGHT TO SERVE AS A REPRESENTATIVE, AS A PRIVATE ATTORNEY GENERAL, OR IN ANY OTHER REPRESENTATIVE CAPACITY, AND/OR TO PARTICIPATE AS A MEMBER OF A CLASS OF CLAIMANTS, IN ANY LAWSUIT FILED AGAINST US AND/OR RELATED THIRD PARTIES.”).

${ }^{141}$ See infra notes $142-143$. 
(1) Courts enforce adhesive arbitration agreements against consumers, employees, and other individuals. ${ }^{142}$

(2) Courts apply the separability doctrine so arbitrators, rather than courts, initially hear defenses to the enforcement of the contracts containing adhesive arbitration agreements, and sometimes even to the enforcement of the arbitration agreement itself. ${ }^{143}$

(3) Courts confirm and enforce arbitration awards without determining whether the arbitrator correctly applied the law. ${ }^{144}$

(4) Adhesive arbitration agreements' class waivers are enforced in circumstances in which such waivers in a non-arbitration agreement would, at least until the Supreme Court's 2011 Concepcion decision, be unenforceable. ${ }^{145}$ So Concepcion and Amex made adhesive

${ }^{142}$ See, e.g., Doctor's Assocs. v. Casarotto, 517 U.S. 681, 683 (1996); Gilmer v. Interstate/ Johnson Lane Corp., 500 U.S. 20, 35 (1991); Perry v. Thomas, 482 U.S. 483, 489-90 (1987); Southland Corp. v. Keating, 465 U.S. 1, 17 (1984). In Gilmer, an important group on the Right, the U.S. Chamber of Commerce, filed an amicus curiae brief for enforcement of the agreement, that is, in support of respondents, Interstate/Johnson Lane Corporation. See Brief for Chamber of Commerce of the U.S. as Amicus Curiae Supporting Respondent, Gilmer v. Interstate/Johnson Lane Corp., 500 U.S. 20 (1991) (No. 90-18), 1990 WL 10009002.

${ }^{143}$ See, e.g., Rent-A-Center, West, Inc. v. Jackson, 561 U.S. 63, 72 (2010); Buckeye Check Cashing, Inc. v. Cardegna, 546 U.S. 440, 445 (2006); Prima Paint Corp. v. Flood \& Conklin Mfg. Co., 388 U.S. 395, 404 (1967). In both Buckeye and Rent-A-Center, an important group on the Right, the U.S. Chamber of Commerce, filed an amicus curiae brief for enforcement of the agreement, that is, in support of the petitioners. See Brief for Chamber of Commerce of the U.S. and the Am. Fin. Servs. Ass'n as Amici Curiae Supporting Petitioner, Buckeye Check Cashing, Inc. v. Cardegna, 546 U.S. 440 (2006) (No. 04-1264), 2005 WL 1976706; Brief for Chamber of Commerce of the U.S. as Amicus Curiae Supporting Petitioner, Rent-A-Center, West, Inc. v. Jackson, 561 U.S. 63 (2010) (No. 09-497), 2010 WL 783668 .

${ }^{144}$ See Hall Street Assocs. v. Mattel, Inc., 552 U.S. 576, 581 (2008) (“[T]he grounds for vacatur and modification provided by $\S \S 10$ and 11 of the FAA are exclusive."); see also id. at 588 (viewing the FAA's provisions on confirmation and vacatur of arbitration awards "as substantiating a national policy favoring arbitration with just the limited review needed to maintain arbitration's essential virtue of resolving disputes straightaway. Any other reading opens the door to the full-bore legal and evidentiary appeals that can render informal arbitration merely a prelude to a more cumbersome and time-consuming judicial review process and bring arbitration theory to grief in post-arbitration process").

${ }^{145}$ See AT\&T Mobility LLC v. Concepcion, 563 U.S. 333, 351-52 (2011) (citing America Online, Inc. v. Superior Court, 108 Cal. Rptr. 2d 699, 712 (Cal. Ct. App. 2001)) (holding that the Federal Arbitration Act preempts California law refusing to enforce adhesive arbitration agreement requiring claims to be brought on an individual, rather than class, basis while acknowledging that California law would not, under similar circumstances, enforce such a requirement in a non-arbitration agreement); $i d$. ("The unavailability of class action relief in this context is sufficient in and by itself to preclude enforcement of the TOS forum selection clause."); see also Martrano v. Quizno's Franchise Co., No. 08-0932, 2009 WL 1704469, at *81 (W.D. Pa. June 15, 2009) (invalidating non-arbitral class waiver); Elhilu v. Quizno's Franchising Co., No. 06-cv-7855, 2008 U.S. Dist. LEXIS 109435, at*15 (C.D. Cal. Apr. 3, 2008) (same); In re Yahoo! Litig., 251 F.R.D. 459, 469-70 (C.D. Cal. 2008) (refusing to hold nonarbitral class waiver enforceable as a matter of law in commercial case and denying motion for summary judgment pending "more developed evidentiary record"). Research revealed only one pre-Concepcion case enforcing a non-arbitral class waiver, Bonanno v. Quizno's Franchise Co., No. 06-cv-02358, 2009 WL 1068744, at*22 (D. Colo. Apr. 20, 2009). But some courts did enforce forum-selection clauses choosing a forum that did not permit class actions. See, e.g., Koch v. America Online, Inc., 139 F. Supp. 2d 690, 695 (D. Md. 2000) 
arbitration agreements more enforceable than other adhesion contracts with respect to class waivers. ${ }^{146}$ Concepcion and Amex allowed businesses to do with adhesive arbitration agreements what other adhesion contracts generally could not do: contain enforceable pre-dispute class waivers.

While current law is at one extreme (the Very Conservative Position), the main alternative that has received significant support in Congress ${ }^{147}$ is the other extreme, the Very Progressive Position, of not enforcing individuals' pre-dispute arbitration agreements at all. Under the Very Progressive Position:

(concluding that unavailability of class actions in Virginia is insufficient reason to refuse to enforce Virginia forum-selection clause); Forrest v. Verizon Commc'ns, Inc., 805 A.2d 1007, 1012 (D.C. 2002) (same); America Online, Inc. v. Booker, 781 So.2d 423, 425 (Fla. Dist. Ct. App. 2001) (per curiam) (same); Gilman v. Wheat, First Sec., Inc., 692 A.2d 454, 464-65 (Md. 1997) (same); see also American Express Co. v. Italian Colors Rest., 133 S. Ct. 2304, 2312 (2013) (holding that an enforceable adhesive arbitration agreement precluded class arbitration or class litigation under circumstances in which a non-arbitration agreement purporting to have that effect would not likely have been enforced); Stolt-Nielsen S.A. v. Animal Feeds Int'l Corp., 559 U.S. 662, 687 (2010) (interpreting an arbitration agreement's silence on class arbitration as a prohibition of it, whereas other contracts' silence on class actions is not generally understood to be a prohibition of them, or at least was not so understood before Stolt-Nielsen and Concepcion). In Concepcion, Stolt-Nielsen, and Italian Colors, the U.S. Chamber of Commerce, an important group on the Right, filed an amicus curiae brief for enforcement of the agreement, that is, in support of the petitioners. See Brief for Chamber of Commerce of the U.S. and Business Roundtable as Amici Curiae Supporting Petitioners, American Express Co. v. Italian Colors Rest., 133 S. Ct. 2304 (2013) (No. 12-133), 2012 WL 6759408; Brief for Chamber of Commerce of the U.S. as Amicus Curiae Supporting Petitioner, AT\&T Mobility LLC v. Concepcion, 563 U.S. 333 (2011) (No. 09-893), 2010 WL 3167313; Brief for Chamber of Commerce of the U.S. as Amicus Curiae Supporting Petitioners, Stolt-Nielsen S.A. v. Animal Feeds Int'l Corp., 559 U.S. 662 (2010) (No. 08-1198), 2009 WL 2875374.

${ }^{146}$ See Peter B. Rutledge \& Christopher Drahozal, "Sticky" Arbitration Clauses? The Use of Arbitration Clauses After Concepcion and Amex, 67 VAND. L. Rev. 955, 964 (2014) ("Unlike arbitral class waivers, nonarbitral class waivers likely remain subject to state unconscionability challenges."); see also id. at 975 (“[A] nonarbitral class waiver . . . poses greater risks of court invalidation. After Concepcion, the FAA provides a substantial degree of protection for arbitral class waivers; nonarbitral class waivers have no such federal law backing. As a result, a number of courts, although certainly not all have refused to enforce nonarbitral class waivers."); Thomas J. Stipanowich, The Third Arbitration Trilogy: Stolt-Nielsen, Rent-ACenter, Concepcion and the Future of American Arbitration, 22 Am. Rev. Int'L ARB. 323, 389 (2011) ("The [Concepcion] Court majority could . . . [have struck] down the arbitration provision [with its class waiver], paving the way for a class action in court. Had there been a class-action waiver without the arbitration provision, that would presumably have been the result."); Maureen A. Weston, The Death of Class Arbitration After Concepcion?, 60 U. KAN. L. REv. 767, 782-84 (2012) (discussing cases upholding class action waivers based on FAA preemption even if state law would invalidate such waivers); U.S. Supreme Court Issues Significant New Decision Regarding Class Action Litigation, WSGR Alert, WILson SonsinI GoODRICH \& Rosati (Apr. 28, 2011) https://www.wsgr.com/WSGR/Display.aspx?Section Name $=$ publications/pdfsearch/wsgralert_class_action_litigation.htm [https://perma.cc/6EN2JBZQ] ("While class waivers outside of arbitration agreements are likely not valid in California, and many other states, [Concepcion] provides powerful ammunition to companies that would prefer to resolve claims through individual arbitration rather than through the court system.”).

${ }^{147}$ See Arbitration Fairness Act of 2013, S. 878, 133th Cong. (2013); supra text accompanying note 35 . 
(1) Courts would not enforce pre-dispute arbitration agreements-let alone adhesive pre-dispute arbitration agreements-against consumers, employees and other individuals. ${ }^{148}$

(2) But, if the law did enforce such arbitration agreements, then courts would be able initially to hear defenses to their enforcement and to the enforcement of the contracts containing them, thus rejecting the separability doctrine. ${ }^{149}$

(3) At least some arbitrators' errors of law would be grounds for vacating the resulting award. ${ }^{150}$

(4) Adhesive arbitration agreements' class waivers would not be enforced at all. ${ }^{151}$

${ }^{148}$ Arbitration Fairness Act of 2013, at $\S 3$ ("Notwithstanding any other provision of this title, no predispute arbitration agreement shall be valid or enforceable if it requires arbitration of an employment dispute, consumer dispute, antitrust dispute, or civil rights dispute.").

${ }^{149}$ Id. ("The applicability of this chapter to an agreement to arbitrate and the validity and enforceability of an agreement to which this chapter applies shall be determined by a court, rather than an arbitrator, irrespective of whether the party resisting arbitration challenges the arbitration agreement specifically or in conjunction with other terms of the contract containing such agreement.").

${ }^{150}$ Proposals to increase vacatur due to arbitrators' legal errors come less from legislators than from scholars. See, e.g., Thomas V. Burch, Regulating Mandatory Arbitration, 2011 UtAH L. Rev. 1309, 1353 (2011) ("[A]rbitrators should be required to issue written awards in mandatory arbitrations, and nondrafting parties should be able to challenge those awards for legal error."); Paul F. Kirgis, Judicial Review and the Limits of Arbitral Authority: Lessons from the Law of Contract, 81 ST. JoHN's L. REv. 99, 120-21 (2007) ("When arbitrators decide questions raising mandatory legal rules . . . there is no logical reason to exempt it from the procedural guarantees that apply in every other adjudicative context. One of those guarantees is a right to some level of meaningful review."); Richard E. Speidel, Arbitration of Statutory Rights Under the Federal Arbitration Act: The Case for Reform, 4 OHIо ST. J. ON Disp. Resol. 157, 157-58 (1989) ("[C]ourts should have clear authority, when statutory claims are involved, to vacate or modify an arbitrator's award where arbitral procedures denied an adequate hearing or where the arbitrator made a [sic] error of law."); Jeffrey W. Stempel, Asymmetric Dynamism and Acceptable Judicial Review of Arbitration Awards, 5 Y.B. ON Arb. \& MediATION 1, 52 (2013) (asserting that there is "a strong case for providing broader judicial review of arbitration awards stemming from modern mass arbitrations and vacating them when they make errors of law or fact that would result in reversal of trial court decisions containing the same errors"); Stephen J. Ware, Default Rules from Mandatory Rules: Privatizing Law Through Arbitration, 83 MinN. L. REv. 703, 739 (1999) (“[C]ourts should review arbitrators' legal rulings on claims arising out of mandatory rules, but not on claims arising out of default rules."); id. at 704 ("The [Supreme] Court must either reverse its decisions that claims arising under otherwise mandatory rules are arbitrable, or require de novo judicial review of arbitrator's legal rulings on such claims."); Nancy A. Welsh, Mandatory Predispute Consumer Arbitration, Structural Bias, and Incentivizing Procedural Safeguards, 42 Sw. L. Rev. 187, 207 (2012) (noting that several scholars have "begun to urge more rigorous judicial review [of arbitration awards] in the disparate party context," that is, the context in which one party is a "more powerful repeat player," typically a business, and the other is a "one-time player," typically a consumer or employee of the business).

${ }^{151}$ The CFPB is considering a proposal that "would ban companies from including arbitration clauses that block class action lawsuits in their consumer contracts." CFPB Considers Proposal to Ban Arbitration Clauses that Allow Companies to Avoid Accountability to Their Customers, Consumer Fin. Protection Bureau (Oct. 7, 2015) http://www.consumerfinance .gov/newsroom/cfpb-considers-proposal-to-ban-arbitration-clauses-that-allow-companies-toavoid-accountability-to-their-customers/ [https://perma.cc/8M22-4RWB]. Similarly, the Arbitration Fairness Act would have this effect because it would render unenforceable nearly all 
While current law is at one extreme, and the main reform with support in Congress would go to the other extreme, this Article proposes the Centrist Position in between the extremes. This Article proposes:

(1) Courts should enforce adhesive arbitration agreements against consumers, employees, and other individuals. ${ }^{152}$

(2) But, courts should be able initially to hear defenses to enforcement of adhesive arbitration agreements and to enforcement of the contracts containing them, thus rejecting the separability doctrine. ${ }^{153}$

(3) Courts should vacate legally erroneous arbitration awards arising out of adhesive and other pre-dispute arbitration agreements, if the arbitrator's error was on a claim arising out of mandatory law, as opposed to a default rule. ${ }^{154}$

(4) Adhesive arbitration agreements' class waivers should be enforced only under circumstances in which non-arbitral class waivers would be enforced. ${ }^{155}$

These proposals - the Centrist Position-could eventually be adopted by Congress in a statute or by the Supreme Court. More immediate, however, is the prospect of a CFPB rule. Therefore, this Article's Appendix contains the language of a rule the CFPB could adopt to enact into law the reforms advocated in this Article. While this rule might be challenged as exceeding the Bureau's authority, such a challenge should fail because the Dodd-Frank Act broadly authorizes the Bureau to "prohibit or impose conditions or limitations on the use of" pre-dispute arbitration agreements in many consumer

adhesive arbitration agreements, whether or not parties seek to assert claims on a class basis. See supra note 148 and accompanying text. A more moderate proposal by Sarah Rudolph Cole would retain enforceability of adhesive arbitration agreements while negating their class waivers. See Sarah Rudolph Cole, On Babies and Bathwater: The Arbitration Fairness Act and the Supreme Court's Recent Arbitration Jurisprudence, 48 Hous. L. Rev. 457, 493 (2011) (arguing that the Arbitration Fairness Act's "[e]liminating predispute arbitration agreements signed by consumers and employees is excessively overbroad"); $i d$. at 498 (proposing "Consumer Class Action and Class Arbitration Waiver Reform Act" which states: "An arbitration agreement between a consumer and a provider of goods or services is invalid to the extent that it precludes the consumer from accessing the court or arbitral system to participate in a class action as defined by Federal Rule of Civil Procedure 23"); see also id. at 497 ("Class actions may be brought under circumstances in which they are necessary for the parties to be able to vindicate their legal rights." (quoting Lew Maltby, Model Arbitration Act (on file with Houston Law Review))).

${ }^{152}$ See Ware, The Case for Enforcing, supra note 72, at 253.

${ }^{153}$ See Stephen J. Ware, Arbitration Law's Separability Doctrine After Buckeye Check Cashing, Inc. v. Cardegna, 8 Nev. L.J. 107, 134 (2007).

${ }^{154}$ See Ware, Vacating Legally-Erroneous Arbitration Awards, supra note 72, at 72.

${ }^{155}$ This Article proposes not the Progressive position that would prohibit enforcement of adhesive arbitration agreements' class waivers but the more centrist position that such provisions be as enforceable as they would be if contained in a non-arbitration agreement. For other moderate positions on class waivers, see supra note 146. 
financial services contracts. ${ }^{156}$ The proposed rule would impose conditions and limitations on such agreements.

\section{CONClusion}

The basic principle behind the Centrist Position is that, with few and relatively uncontroversial exceptions, ${ }^{157}$ adhesive arbitration agreements should be as enforceable as other adhesion contracts, but not more so. In other words, this Article rejects conservative-supported anomalies that enforce adhesive arbitration agreements more broadly than other adhesion contracts, and proposes - contrary to the position advocated by progressivesthat once these anomalies are fixed, adhesive arbitration agreements should be as generally enforceable as other adhesion contracts.

This would have several beneficial effects. First, it would protect consumers and other individuals from enforcement of contracts that, outside the arbitration context, our law would not enforce because of the presence of a contract-law defense, a prohibition on appealing legally-erroneous decisions, or a prohibition on class actions. Second, it would protect the freedom of individuals and other parties to choose, within the bounds of generally applicable law, what agreements to make, and thus what set of rights and duties to acquire. Finally, it would strengthen arbitration as an alternative process of dispute resolution, providing healthy competition to government courts and facilitating access to justice for a variety of claims.

15612 U.S.C. § 5518(b) (2012); see also CompuCredit Corp. v. Greenwood, 132 S. Ct. 665, 672 (2012) (describing 12 U.S.C. $\$ 5518$ (b) as "granting authority to the newly created Consumer Financial Protection Bureau to regulate predispute arbitration agreements in contracts for consumer financial products or services").

${ }^{157}$ See supra note 133 (discussing discovery, evidence, and jury). 


\section{Appendix: A Proposed CFPB Rule}

This Article proposes that the Consumer Financial Protection Bureau adopt the following rule. It uses terms, such as "covered person" and "consumer," defined in the Dodd-Frank Act. ${ }^{158}$

1. Notwithstanding any law or agreement to the contrary:

a. An agreement between a covered person and a consumer for a consumer financial product or service providing for arbitration of any future dispute between the parties is enforceable save upon such grounds as exist at law or in equity for the revocation of any contract.

b. Whether such agreement or ground exists shall, on request of a party to such alleged agreement, be determined by a court, rather than an arbitrator, irrespective of whether the party resisting arbitration challenges the arbitration agreement specifically or in conjunction with other terms of the contract containing such agreement.

c. If such agreement requires claims to be brought on an individual, rather than class, basis then such requirement shall be as enforceable as such a requirement in a non-arbitration agreement would be under similar circumstances.

2. In addition to other grounds for vacating arbitration awards, a state or federal court shall vacate an award arising out of an agreement between a covered person and a consumer for a consumer financial product or service providing for arbitration of any future dispute between the parties where the award was based on the arbitrators' error of law and, at the time of their most recent agreement submitting the controversy to arbitration, the parties could not have formed an enforceable contract to avoid such law.

Comment: This proposal is intended to overrule (with respect to agreements within the Bureau's jurisdiction) the holding or possible implications of the following cases:

1. Prima Paint Corp. v. Flood \& Conklin Manufacturing Co., 388 U.S. 395 (1967).

2. Buckeye Check Cashing, Inc. v. Cardegna, 546 U.S. 440 (2006).

3. Hall Street Associates, L.L.C. v. Mattel, Inc., 552 U.S. 576 (2008). 
4. Stolt-Nielsen S.A. v. Animal Feeds International Corp., 559 U.S. 662 (2010).

5. Rent-A-Center, West, Inc. v. Jackson, 561 U.S. 63 (2010).

6. AT\&T Mobility LLC v. Concepcion, 131 S. Ct. 1740, 1753 (2011).

7. American Express Co. v. Italian Colors Restaurant, 133 S. Ct. 2304 (2013). 
